\title{
Pain for Profit: An AnAlysis of the LIVE EXPORT TRADE
}

\section{LAURA MORFUNI*}

The current regime for the export of live animals from Australia is in drastic need of reform. Recent media exposés have brought the brutal nature of the live export trade to light. This trade should be abolished. Thus far, legislative attempts to do so have not succeeded. The current legal regime fails to protect the welfare of animals throughout the live export chain. This article examines the protection of animal welfare in the current regulatory system and highlights its deficiencies. It also makes some proposals for reform. For as long as the trade continues, reform is needed to ensure that animal suffering is minimised.

\section{INTRODUCTION}

The legal status of a 'thing' determines its treatment under the law. ${ }^{1}$ Historically, the notion of property has been an essential concept in the development of the law and the law has always protected property rights because they are considered the cornerstone of the economy. ${ }^{2}$ The concept of property encompasses animate and inanimate objects. ${ }^{3}$ Both the common law and Roman law recognised that human beings could be owned as the property of another. Thus, slavery was recognised and the property rights associated with slavery were protected. ${ }^{4}$ For example, until the passage of ameliorating legislation, married women were considered the property of their husbands. ${ }^{5}$

* LLB, BA (Media and Communications) (University of Melbourne).

${ }^{1}$ Gary L Francione, Animals, Property, and the Law (Temple University Press, 1995).

2 John Locke, Two Treatises of Government (Cambridge University Press, $2^{\text {nd }}$ ed, 1967).

${ }^{3}$ Richard A Epstein, 'Animals as Objects, or Subjects, of Rights' in Cass R Sunstein and Martha C Nussbaum (eds), Animal Rights: Current Debates and New Directions (Oxford University Press, 2004).

${ }^{4}$ Alan Watson, 'Rights of Slaves and Other Owned-Animals' (1997) 3 Animal Law 1.

${ }^{5}$ Richard A Posner, 'Animal Rights: Legal, Philosophical and Pragmatic Perspectives' in Cass $\mathrm{R}$ Sunstein and Martha C Nussbaum (eds), Animal Rights: Current Debates and New Directions (Oxford University Press, 2004) 156. 
An individual's status as property determined the manner in which they were treated by the law.

Presently, animals are considered property. ${ }^{6}$ Because animals are considered property, the function of animal welfare law is seen to be to maximise the economic value of the animal rather than to ensure absolute protection of the animal. ${ }^{7}$ Nowhere is this clearer than in the live export trade. Each year, sheep, cattle, goats, deer, camels and buffalo are exported overseas from Australia, mostly to destinations in the Middle East or South East Asia. ${ }^{8}$ In the 2008/09 financial year, 4 million sheep with a value of AUD340 million were exported from Australia. ${ }^{9}$ During the same timeframe, 893000 cattle with a value of AUD651 million were exported. ${ }^{10}$

It is the position of this article that the live export trade should not continue. So long as it does, animals will continue to suffer, irrespective of any efforts at reform. This is because the trade is inherently cruel. Furthermore, it is morally inconsistent for Australia to impose animal welfare requirements while animals are within Australia, yet 'ignore the treatment meted out to Australian animals on arrival in an importing country'. ${ }^{11}$

\footnotetext{
${ }^{6}$ David Favre, 'A New Property Status for Animals: Equitable Self-Ownership' in Sunstein and Nussbaum (eds), above n 5; Francione, above $n 1$.

${ }^{7}$ Francione, above n 1; Gary Francione, Introduction to Animal Rights: Your Child or the Dog? (Temple University Press, 2005); Gary L Francione, 'Animal Rights Theory and Utilitarianism: Relative Normative Guidance’ (1997) 3 Animal Law 76; Gary L Francione, 'Animals - Property or Persons?' in Sunstein and Nussbaum (eds), above n 5; Gary L Francione, 'Equal Consideration and the Interest of Nonhuman Animals in Continued Existence: A Response to Professor Sunstein' (2006) University of Chicago Legal Forum 231; Gary L Francione, 'Reflections on Animals, Property and the Law and Rain Without Thunder' (2007) 70 Law and Contemporary Problems 9.

${ }^{8}$ R T Norris and G J Norman, Meat and Livestock Australia, National Livestock Export Industry Shipboard Performance Report 2008 (2009); R T Norris and G J Norman, Meat and Livestock Australia, National Livestock Export Industry Shipboard Performance Report 2007 (2008); R T Norris and G J Norman, Meat and Livestock Australia, National Livestock Exports Mortality Summary 2006 (2007); R T Norris and G J Norman, Meat and Livestock Australia, National Livestock Exports Mortality Summary 2004 (2005); Meat and Livestock Australia and Livecorp, Australian Livestock Export Industry, Year in Review (2009); Meat and Livestock Australia, Asia Pacific (2009); Meat and Livestock Australia, Middle East and Africa (2009); Meat and Livestock Australia, Facts and Figures (2009).

${ }^{9}$ Meat and Livestock Australia and Livecorp, Australian Livestock Export Industry, Year in Review (2009); Meat and Livestock Australia, Facts and Figures (2009).

${ }^{10}$ Ibid.

${ }^{11}$ Malcolm Caulfield, Handbook of Australian Animal Cruelty Law (Animals Australia, 2009) 75 .
} 
Part II of this article details the history of the live export industry in Australia. The industry has a bloody history marred by poor animal welfare practices. Notwithstanding the multiple inquiries held to investigate the live export trade - all of which offer some criticism of the process and its detrimental impact on animal welfare - the trade continues.

Part III examines current obstacles preventing reform of the live export trade and offers a cursory description of the live export regime. Currently, there is no uniform regime that protects the welfare of exported animals. The regulatory function is divided between the Commonwealth and the states: the right to export animals is regulated by the Commonwealth, ${ }^{12}$ the welfare of animals is regulated by state law. ${ }^{13}$ This duality results in a regime characterised by a multiplicity of statutes, regulations, orders and state animal welfare laws. ${ }^{14}$

The deficiencies of the regime are considered in Part IV. The exported animals are commodities for trade. The legislation that governs their export is not primarily concerned with animal welfare but rather the regulation of exports: the system protects the welfare of animals only to the extent necessary to maximise the economic return to be gained from them.

Part V puts forward some proposals for reform. The live export trade should be abolished because of its failure to protect animal welfare. The trade is inherently cruel from beginning to end. Certain stressors imposed on animals during the journey can never be alleviated through increased regulation. However, at the time of writing, it seems that abolition is unlikely to be achieved in the short term because of the perceived economic loss that it would produce for Australian farmers and the export industry. If abolition of live export cannot be achieved, then it is necessary to ensure that the law properly protects animal welfare. At a minimum this requires better monitoring of the treatment of animals throughout export and the prosecution of those who are complicit in breaching animal welfare standards. A live export system that prioritises animal welfare would require: clear and enforceable animal welfare protection laws to ensure that the welfare of

\footnotetext{
${ }^{12}$ Export Control Act 1982 (Cth).

${ }^{13}$ See, eg, Animal Welfare Act 2002 (WA).

${ }^{14}$ Australian Meat and Livestock Industry Act 1997 (Cth); Australian Meat and Livestock Industry (Export Licensing) Regulations 1998 (Cth); Australian Meat and Live-stock Industry (Standards) Order 2005 (Cth); Export Control Act 1982 (Cth); Export Control (Orders) Regulations 1982 (Cth); Export Control (Animals) Order 2004 (Cth); Department of Agriculture, Fisheries and Forestry, Australian Position Statement on the Export of Livestock (2006); Department of Agriculture, Fisheries and Forestry, Australian Standards for the Export of Livestock: Version 2.3 (2011); Animal Welfare Act 2002 (WA).
} 
animals is protected; clear and enforceable animal welfare standards to ensure that all individuals are aware of their obligations; more aggressive enforcement of laws in the event of breach; and thorough veterinary checks of animals prior to export to ensure that ill and weak animals are not exported. This article argues that the current regulatory regime fails to meet these minimum requirements and thus must be reformed if the trade is to continue. Where it refers to state legislation, the article uses Western Australian legislation as a model. This is because Western Australia is the nucleus for the live export regime: 80 per cent of Australia's live sheep exports depart from the port of Fremantle. Although many species are exported from Australia, this article focuses predominantly on sheep and cattle as they are most commonly exported.

\section{THE LIVE EXPORT REgIME}

In 1985, an inquiry into the export of sheep from Australia to the Middle East concluded that

if a decision were to be made on the future of the trade purely on animal welfare grounds, there is enough evidence to stop the trade. The trade is, in many respects, inimical to good animal welfare, and it is not in the interests of the animal to be transported to the Middle East for slaughter. ${ }^{15}$

The Senate committee conducting the inquiry found that 'economic and other considerations' required the trade to continue at the time. ${ }^{16}$ However, it indicated that a long-term solution to improving or replacing the trade must be sought. ${ }^{17}$

The live export regime has long been subject to public scrutiny. In 2002, on the 27-day maiden voyage of the livestock carrier $M V$ Becrux, 569 cattle (30 per cent of the original consignment) and 1418 sheep (around 2 per cent of the original consignment) perished. The primary cause of death was heat stress, caused by the inability of the animals to acclimatise to the sudden change in temperature as the ship crossed the Equator. This was exacerbated by inadequate ventilation on board. ${ }^{18}$

\footnotetext{
${ }^{15}$ Senate Select Committee on Animal Welfare, Parliament of Australia, Export of Live Sheep from Australia (1985) 185.

${ }^{16}$ Ibid.

${ }^{17}$ Ibid 186.

${ }^{18}$ Simon More, Independent Reference Group, Investigation of Cattle Deaths during Voyage 1 of the MV Becrux (2002).
} 
In August 2003, a consignment of 57937 sheep spent 80 days languishing on the Cormo Express in Middle Eastern waters after the shipment was rejected by the Saudi Government. Eventually, a diplomatic agreement was reached and the animals disembarked in Eritrea. By the time they arrived, 5691 animals -9.82 per cent of the consignment - had died. ${ }^{19}$

At that time, the current affairs television program 60 Minutes aired a series of reports investigating the live export trade. It alleged that ship-hands on the Cormo Express disposed of newborn lambs and dying sheep by throwing them alive into large mincers. ${ }^{20}$ Other footage showed Egyptian abattoir workers cutting the Achilles tendons of cattle prior to slaughter so as to render them helpless. ${ }^{21}$ Following the broadcast, live export to Egypt was temporarily suspended.

In 2003, following the Cormo Express incident, the government initiated a review of the self-regulated industry (the 'Keniry Review') in response to media coverage and public outcry. ${ }^{22}$ At the time of the review, two industry bodies, Meat and Livestock Australia ('MLA') and Livecorp were responsible for ensuring that producers complied with export regulations. The Keniry Review commenced on 10 October 2003 and published a final report on 23 December 2003. Given the tight timeframe of the Review, its scope was limited. The report focused on the export of animals to the Middle East. The

${ }^{19}$ Department of Local Government and Regional Development $v$ Emanuel Exports Magistrates Court of WA (Criminal Jurisdiction) 8 February 2008, (Crawford M), [29] ('Emanuel Exports'). See also, Clive J C Philips 'The Welfare of Livestock during Sea Transport' (Paper presented at RSPCA Australia Scientific Seminar, CSIRO Discovery Centre, Canberra, 26 February 2008), 10; Simon More, Independent Reference Group, Investigation of Cattle Deaths During Voyage 1 of the MV Becrux (2002).

${ }^{20}$ Channel Nine, 'Ship of Shame', 60 Minutes, September 21, 2003 (Richard Carleton) $<$ http://sixtyminutes.ninemsn.com.au/article/259096/ship-of-shame>.

${ }^{21}$ Channel Nine, 'Making a Killing', 60 Minutes July 27, 2003 (Richard Carleton) <http:// sixtyminutes.ninemsn.com.au/webchats/263805/making-a-killing-animal-welfare $>$. See also, Channel Nine, 'A Cruel Trade', 60 Minutes, February 26, 2006 (Richard Carleton) $<$ http://sixtyminutes.ninemsn.com.au/stories/richardcarleton/259366/a-cruel-trade>.

${ }^{22}$ John Keniry et al, Department of Agriculture, Fisheries and Forestry, Live Export Review (2003). See also 'Cormo Express Managers Relieved at End to Sheep Saga', The Sydney Morning Herald (online), 25 October $2003 \quad<$ http://www.smh. com.au/articles/2003/10/26/1067103265620.html>; Orietta Guerrera 'Cormo Express Delayed in Kuwait', The Age (online), 7 October $2003<\mathrm{http} / /$ www.theage.com.au/ articles/2003/10/06/1065292529144.html?from=storyrhs $>$. Political commentators suggested that the government's handling of the Cormo saga was a 'vote loser' and the 'Tampa of the live sheep export trade': Ron Tandberg, The Age (Melbourne), 25 September 2003 $<$ http://www.nma.gov.au/exhibitions/past_exhibitions/behind_the_lines/cormo_express/slides how_1_2.html>; Michelle Grattan, 'Sheep Onboard a National Shame', The Age (online), 24 September $2003<$ http://www.theage.com.au/articles/2003/09/23/1064082991895.html>. 
majority of submissions were made by individuals. Only one scientific submission was provided. Accordingly, the Inquiry's findings cannot be considered exhaustive.

The terms of reference directed the Review to evaluate: the applicability of the model codes of practice to live export; the self-regulatory regime that governed the industry at the time; the types of livestock suitable for export; the utility of supervision on export voyages; and the specific factors contributing to the Cormo mortalities. It recognised that the industry is 'inherently risky because it deals with sentient animals along an extended production chain'.

The Review lambasted the industry's self regulatory efforts. It noted that animals exported from Australia carry the 'Australian brand' and 'for this reason, if no other, the Australian Government has carried a greater degree of responsibility for ensuring the integrity of the trade and guaranteeing its quality'. ${ }^{24}$ Accordingly, the Review's report made the following recommendations: that the Commonwealth government be responsible for the granting of export licences and permits; $;{ }^{25}$ that national standards for live export be established; ${ }^{26}$ that the issue of permits be closely linked to an assessment of the exporter's work history and the capability of the exporter to meet national live export standards $;^{27}$ that veterinarians accompany all export voyages longer than 10 days and provide reports to the Australian Quarantine and Inspection Service ('AQIS') about shipping conditions and mortality rates; and that those veterinarians travelling on board live stock carriers 'be directly contractible and accountable to AQIS'. ${ }^{28}$

Ultimately, the fundamental recommendation of the Review - that the Commonwealth government be responsible for the regulation of the industry - was adopted and thus the government is currently in charge of the live export industry. The Explanatory Memorandum of the Agriculture, Fisheries and Forestry Legislation Amendment (Export Control) Bill 2004 indicated that the government accepted the recommendation that national standards be developed. ${ }^{29}$ Some critics, however, have suggested that this was not actually

\footnotetext{
${ }^{23}$ Keniry et al, above $\mathrm{n} 22,4$.

${ }^{24}$ Ibid 14.

${ }^{25}$ Ibid 5 (Recommendation 2).

${ }^{26}$ Ibid 5 (Recommendation 1).

${ }^{27}$ Ibid (Recommendation 3).

${ }^{28}$ Ibid 6 (Recommendation 4).

${ }^{29}$ Explanatory Memorandum, Agriculture, Fisheries and Forestry Legislation Amendment (Export Control) Bill 2004 (Cth).
} 
achieved because there is no requirement that the standards be reviewed by Parliament. ${ }^{30}$

In May 2011, over two decades after the first government inquiry into live export recommended that the trade be phased out, the ABC's Four Corners programme broadcast an horrific exposé of the treatment of Australian animals in Indonesian abattoirs. The public response elicited by the programme was such that trade with Indonesia was temporarily ceased. On 8 July 2011, trade resumed on the condition that animals only be exported to specific abattoirs that comply with the standards set by the World Animal Health Organisation. ${ }^{31}$ At the time of writing, the controversy continues. Two Bills to end live export have been rejected by Parliament, with only the Greens and Independents voting in favour of a ban. Australia continues to export live animals to countries in the Middle East and Asia. Footage of cattle being beaten with spike-tipped poles has been released. ${ }^{32}$ Further footage of animal abuse showing conscious animals being strung up by their back legs before having their throats cut in Turkish abattoirs has also been released. ${ }^{33} \mathrm{~A}$ shipload of 67000 sheep was stranded at sea for several days when the engine failed shortly after its departure from Australia, highlighting the poor condition of some livestock carriers. ${ }^{34}$

${ }^{30}$ This is because they are in the form of delegated legislation: Caulfield, above n 11, 88 and 137.

31 'Labor MPs Revolt as Live Export Ban Lifted' The Age (online) 8 July 2011 $<$ http://www.theage.com.au/environment/animals/labor-mps-revolt-as-live-export-ban-lifted20110708-1h5xk.html>. See also, 'No Guarantees as Live-Export Checking System Unveiled' The Age (online) 21 October 2011 <http://www.theage.com.au/ environment/animals/no-guarantees-as-live-export-checking-system-unveiled-201110211mbzg.html>.

32 Animals Australia, Live Export Cruelty in Israel Revealed (25 August 2011) Animals Australia $<\mathrm{http}$ ///animalsaustralia.org/features/live-export-cruelty-israel.php $>$. The footage was gathered by the organisation Anonymous for Animals Rights.

${ }^{33}$ Glenda Kwek, 'Live Animal Export Outrage: "Horrendous Slaughter" of Cattle' The Age (online) 18 August $2011<\mathrm{http} / /$ www.theage.com.au/environment/animals/live-animalexport-outrage-horrendous-slaughter-of-cattle-20110818-1iz2i.html>.

34 '67,000 Sheep Stranded as Live-Export Ship Breaks Down' The Age (online) 16 August $2011<\mathrm{http}: / /$ www.theage.com.au/environment/animals/67000-sheep-stranded-as-liveexportship-breaks-down-20110816-1ivwn.html>; Tom Allard and Richard Willingham, 'Stranded Sheep Reignite Live Export Fears' The Age (online) 17 August 2011 $<$ http://www.theage.com.au/national/stranded-sheep-reignite-live-export-fears-20110816-1iw f5.html>. 


\section{The LaW and Animal Welfare}

Live export is inconsistent with both the government policy on animal welfare and the law relating to cruelty to animals. It is inconsistent with government policy because the policy states that 'animal welfare' encompasses 'all aspects of animal health and well being, including proper housing, management ... nutrition, disease prevention and treatment, responsible care, humane handling, and, when necessary, humane killing ${ }^{35}$ However, industry practice fails to ensure proper management, nutrition, disease prevention and humane handling of the animals throughout the live export chain. ${ }^{36}$ Live export is inconsistent with the law because animal welfare legislation provides that harming an animal is permitted unless the harm is 'unnecessary,. ${ }^{37}$ Yet, in the live export trade the harm inflicted is unnecessary because it is rationalised only by economic reasons, which do not constitute a sufficient justification for causing harm to animals at law. ${ }^{38}$ The regime is also inconsistent because, notwithstanding any animal welfare measures that are imposed on animals exported from Australia, animals cannot be protected by Australian law upon their arrival at the port of destination. Accordingly, once in the foreign country, animals may be subject to treatment that is forbidden in Australia.

\section{A Animal Welfare Law}

Animal welfare law balances the humane treatment of animals against the maximisation of the profitable use of an animal. The legal system manages these two competing interests by requiring animal welfare to be considered when an evaluation is being made as to whether conduct towards an animal is cruel or inhumane. This translates into the proposition that no greater harm should be inflicted than is necessary to achieve the most efficient use of the

\footnotetext{
${ }^{35}$ National Consultative Committee on Animal Welfare, Position Statement May 2006: Animal Welfare, Animal Liberation and Animal Rights (21 July 2008) Department of Agriculture, Fisheries and Forestry.

${ }^{36}$ See below, Part IV(A).

${ }^{37}$ Animal Welfare Act 2002 (WA) s 19. Note that other state Acts also prohibit 'unjustifiable' or 'unreasonable' harm: see, eg, Animal Welfare Act 1993 (Tas) ss 7, 8. As Francione notes, ' $[t]$ he interests of property will almost never be judged as similar to the interests of property owners' and thus, it is rare that courts find an individual's conduct towards an animal is unjustified, unreasonable or unnecessary: Francione, 'Reflections', above n 7, 38. For a discussion on how the law considers that it may be necessary to inflict some harm 'to achieve the efficient use of the animal as an economic resource', see Francione, 'Introduction to Animal Rights', above n 7, 67. An analysis of the ethical propriety of the conceptualisation of animals as property is beyond the scope of this article.

${ }^{38}$ Emanuel Exports Magistrates Court of WA (Criminal Jurisdiction) 8 February 2008 (Crawford M).
} 
animal. Accordingly, maximisation of profit must eventually yield to animal welfare. ${ }^{39}$

A regime that condones necessary harm must be adequately and strictly enforced to ensure that any unnecessary harm to animals is eradicated. As discussed below, there is a notable lack of monitoring of compliance with, and enforcement of, animal welfare law within the live export industry. In situations where the conduct is considered so cruel that it cannot be justified, the legislation imposes a complete ban. ${ }^{40}$ The protection of animal welfare in Australia is state-based: each state has Prevention of Cruelty to Animals ('POCTA') legislation.

The justification for live export is the belief that the trade maximises the financial return to be gained from the animal. However, the law indicates that infliction of harm to achieve that end may be unlawful. In defining what constitutes 'necessary harm', it was recognised by Lord Chief Justice Coleridge as long ago as 1889 that:

it is not necessary to sell beasts for 40 [shillings] more than could otherwise be obtained for them; nor to pack away a few more beasts in a farm yard, or a railway truck, than could otherwise be packed ... These things may be convenient or profitable to the owners of cattle, but they cannot with any show of reason be called necessary. ${ }^{41}$

Yet, the maximisation of financial return is the genesis and impetus of the live export trade. The trade is fuelled by a belief that farmers get more money selling their animals for shipment overseas than selling them within Australia. ${ }^{42}$ Throughout the entire live export chain, financial considerations reign supreme as animal welfare is disregarded in the pursuit of profit. Thus, animals are given pelleted feed because it is cheaper than hay or chaff for the animals, notwithstanding that some animals do not adapt sufficiently to pelleted feed. ${ }^{43}$ Sheep may be stocked three per square metre because a higher

\footnotetext{
${ }^{39}$ This threshold, however, is extremely high. See, eg, Peter Sankoff, 'The Welfare Paradigm: Making the World a Better Place for Animals?' in Peter Sankoff and Steven White, Animal Law in Australasia: A New Dialogue (Federation Press, 2009).

${ }^{40}$ Ibid 29.

${ }^{41}$ Ford $v$ Wiley (1889) 23 QB 203 (Coleridge LCJ). In the context of live export, it has also been held that financial gain, when balanced against the likelihood of pain or death, does not meet the threshold requirement for necessary harm. Emanuel Exports Magistrates Court of WA (Criminal Jurisdiction) 8 February 2008, [99] (Crawford M).

${ }^{42}$ Commonwealth, Parliamentary Debates, Senate, 29 March 2006, 179 (Senator McGauren).

${ }^{43}$ Emanuel Exports Magistrates Court of WA (Criminal Jurisdiction) 8 February 2008.
} 
stocking density enables a greater number of animals per shipment. ${ }^{44}$ It is a sad reflection on the lack of will to safeguard animal welfare that little progress appears to have been made since Lord Chief Justice Coleridge noted that convenience and profit, whilst beneficial for owners, are still cruel. Although Lord Chief Justice Coleridge noted this over a century ago, the trade continues, despite its infliction of pain for profit.

The live export regime also infringes the ethical concept of animal welfare. Animal welfare is described by the Department of Agriculture, Fisheries and Forestry ('DAFF') as requiring that animals are 'healthy, properly fed and comfortable and that efforts are made to improve their well-being and living conditions'. ${ }^{45}$ Thus, the concept of 'humane treatment' of animals is critical to an understanding of good animal welfare. ${ }^{46}$ Humane treatment is achieved by managing animals in a manner that does not cause them unnecessary stress and suffering. This may be achieved in a number of ways. Studies show, for example, that lambs become stressed as a consequence of underfeeding. ${ }^{47}$ It is also widely accepted that animals will be stressed or alarmed by loud noises, sudden movement and rough handling. ${ }^{48}$ The Australian government has issued publications in Arabic for animal handlers in the Middle East. The publications reflect this understanding of animal welfare in the information they provide about appropriate animal handling. ${ }^{49}$

Despite the nexus between humane treatment and animal welfare, the industry measures animal welfare through mortality rates. If mortality rates are low, it is presumed that animal welfare standards are being met. For example, in 2008/09, approximately 33600 sheep and 1032 head of cattle died during export. ${ }^{50}$ These figures did not exceed the industry-accepted mortality rates. Given that good animal welfare calls for a happy, calm and healthy animal, the conflation of welfare with mortality is deficient. By itself, mortality tells

\footnotetext{
${ }^{44}$ Department of Agriculture, Fisheries and Forestry, Australian Standards for the Export of Livestock: Version 2.3 (2011), s 5.6(4.1.3).

${ }^{45}$ Department of Agriculture, Fisheries and Forestry, The Australian Animal Welfare Strategy, (2008), 18.

${ }^{46}$ Kathleen Plowman, Alan Pearson and John Topfer, 'Animals and the Law in Australia: a Livestock Industry Perspective' (2008) 81 Reform 25.

${ }^{47}$ N G Gregory, 'Animal Welfare at Markets and during Transport and Slaughter' (2008) 2 Meat Science 11.

${ }^{48}$ Meat and Livestock Australia, LiveCorp and Department of Agriculture, Fisheries and Forestry Livestock Handling Guide (2008).

${ }^{49}$ Ibid 8.

${ }^{50}$ Norris and Norman, 'Performance Report 2008' above n 8, 1.
} 
us 'very little about [animal] ... welfare' ${ }^{51}$ The concept of animal welfare recognises that animals may suffer harm that does not result in death. ${ }^{52}$ Yet this is not reflected in the current standards of the live export regime.

\section{B Animal Welfare during Live Export}

The welfare of animals is compromised during live export. The cumulative effects of road transport, yarding and handling in conjunction with dietary and climatic changes all affect animals' health and welfare.$^{53}$ Animals sourced for live export endure lengthy periods of transportation from the farm to the dockside premises where they are kept to adjust to pelleted feed. ${ }^{54}$ During this transportation they may suffer trauma injuries and may go without water for up to 24 hours. ${ }^{55}$ Animals must then survive sea transportation. During the voyage, animals experience sudden changes in heat and humidity as the ships cross the Equator. ${ }^{56}$ Most cattle deaths during live export are attributable to heat stress which is caused by a combination of the factors listed above. ${ }^{57}$ Sheep are particularly susceptible to inanition (failure to eat) and

${ }^{51}$ Robert Garner, Animals, Politics and Morality (Manchester University Press, $2^{\text {nd }}$ ed, 2004), 113.

${ }^{52}$ Emanuel Exports Magistrates Court of WA (Criminal Jurisdiction) 8 February 2008.

${ }^{53}$ Sub-Committee on Animal Welfare, Standing Committee on Agriculture Animal Health Committee, Parliament of Australia, Model Code of Practice for the Welfare of Animals 8: Sea Transport of Livestock (1987), 84-5.

${ }^{54}$ Norris and Norman, 'Mortality Summary 2004', above n 8, 27; Philips, above n 19, 6-7.

${ }^{55}$ Standard 2.6(2.8) provides that during land transportation animals may be deprived of water no longer than 12 hours. However, standard 3.6(3.14) provides that animals may be deprived of food and water no longer than 12 hours after arrival. Thus, if a truckload of animals takes just under 12 hours to arrive at registered premises and the animals are unloaded and not fed for close to another 12 hours, they have gone without sustenance and water for 24 hours. Department of Agriculture, Fisheries and Forestry, Australian Standards for the Export of Livestock: Version 2.3 (2011). See also Norris and Norman, 'Mortality Summary 2004', above n 8, 27; Philips above n 19, 6-7.

${ }^{56}$ Norris and Norman, 'Mortality Summary 2004', above n 8, 27; Philips, above n 19, 6-7. It is the lack of acclimatisation that led to the excessive number of deaths on the MV Becrux: the animals were sourced from Southern Australia in the middle of an Australian winter. Accordingly, they had long winter coats and stores of subcutaneous fat to protect them in that climate. It was noted that the rate of deaths amongst the cattle increased as the ship continued into a warmer climate: the animals were not prepared for the sudden change in temperature and most died from heat stress: More, above n 18, 12.

${ }^{57}$ Independent Reference Group, A Way Forward on Animal Welfare: A Report on the Live Export Industry (2002); More, above n 18, 12; Philips, above n 19, 8; Frank Drum and Caroline Gunning-Trant 'Live Animal Exports: A Profile of the Australian Industry' (Abare Research Report 08.1, February 2008, Parliament of Australia), 19; R T Norris, 'Transport of Animals by Sea' (2005) 24 Revue Scientifique and Technique Office Internationale de Epizooties 673. 
salmonellosis (gastroenteritis infection) throughout the export chain. ${ }^{58}$ These two causes of death are often linked. Inanition develops when sheep fail to adapt to the pelleted feed that is provided to them at the feedlot. Because they stop eating, they become weak and fall victim to salmonellosis and other infections. ${ }^{59}$

Animal welfare is also compromised once the animals arrive at a foreign port for slaughter. Many animals exported from Australia are slaughtered by having their throat cut while they are conscious. ${ }^{60}$ Allegedly, this is because the animals are slaughtered in accordance with Halal ritual. However, it is generally accepted that animals may be stunned so they are unconscious prior to having their throat cut: the meat will still be considered Halal because the death is caused by blood loss from cutting the throat after the animal is stunned, not the stunning itself. ${ }^{61}$

Irrespective of whether stunning is compatible with Halal slaughter, the fact remains that Australian animals are killed in abattoirs where killing and handling practices are not compliant with Halal stipulations. Halal slaughter requires, amongst other things, that the animals be faced towards Mecca and slaughtered with a cut to the throat. ${ }^{62}$ The cut must be swift and made in a single movement, severing the arteries in the neck, the trachea and the oesophagus so as to cause as little pain as possible. ${ }^{63}$ It further requires that the animals be handled gently and that they not be killed in the presence of others. ${ }^{64}$ However, investigations by Animals Australia have found that

in larger Middle East[ern] abattoirs where approximately 2000 to 3000 sheep would be slaughtered each night, it is common practice to drag a sheep by its hind leg (away from a watching herd), turn the sheep upside

\footnotetext{
${ }^{58}$ Drum and Gunning-Trant, above n 57; Norris, above n 57.

${ }^{59}$ Caulfield, above n 11, 77.

${ }^{60}$ Graeme McEwen, The Australian Government's Role in the Live Animal Trade: A Policy Veneer (6 August 2007) Barristers Animal Welfare Panel <http://www.bawp.org.au/currentissues/live-exports> [3]. See also, Nick Cohen 'God's Own Chosen Meat' New Statesman 5 July 2004, 22; Florence Bergeaud-Blackler, 'New Challenges for Islamic Ritual Slaughter: A European Perspective' (2007) 33 Journal of Ethnic and Migration Studies 966; Karijn Bonne and Wim Verbeke, 'Religious Values Informing Halal Meat Production and the Control and Delivery of Halal Credence Quality' (2008) 25 Agriculture and Human Values 35.

${ }^{61}$ Bonne and Verbeke, above n 60, 41.

${ }^{62}$ McEwen, above $\mathrm{n}$ 60, [3].

${ }^{63}$ Temple Grandin and Joe M Regenstein, 'Religious Slaughter and Animal Welfare: A Discussion for Meat Scientists' (1994) Meat Focus International 115; McEwen, above n 60, [3]. See also, Cohen, above n 60; Bergeaud-Blackler, above n 60, 966; Bonne and Verbeke, above $\mathrm{n} 60,35$.

${ }^{64}$ McEwen, above n 60, [3].
} 
down over a drain (often where other sheep lie whose throats have just been cut and are still writhing), cut the throat of the sheep (frequently taking three separate motions to sever the windpipe and major blood vessels), then leave the conscious sheep to 'bleed out'. 65

Similarly, the footage of Indonesian abattoirs showed cows being tortured by abattoir workers before being killed in front of other animals. The footage from Turkey shows animals being stabbed in the neck, rather than having their throats cut. These practices are inconsistent with Halal slaughtering requirements. Furthermore, they cause unnecessary pain and suffering to the animals. Studies conducted by Temple Grandin have found that when a 'slower, less decisive stroke [is] used [to slaughter conscious animals], there [is] an increased incidence of prolonged sensibility'. ${ }^{66}$ Further studies have shown that conscious animals experience stress and panic when their throat is cut. ${ }^{67}$ Sheep usually take at least 10 seconds to lose consciousness when their throat is cut. Cattle often take longer than 100 seconds to lose consciousness. ${ }^{68}$ Accordingly, animals exported to countries where they are not stunned before slaughter may experience pain and fear during slaughter until blood-loss renders them insensible. ${ }^{69}$ Furthermore, many animals exported from Australia are sold to private purchasers with little or no butchery skills. It has been proved that poor cutting technique 'often causes vigorous struggling' which indicates that the animal experiences a sensation of pain, discomfort or panic. ${ }^{70}$ The sale of animals to private purchasers for slaughter thus compromises animal welfare. ${ }^{71}$

\section{The Law Governing Live Export}

Presently, regulation of the export of animals is controlled via a licensing system that is executed by the Secretary of DAFF and the Secretary's

\footnotetext{
${ }^{65}$ Ibid.

${ }^{66}$ Grandin and Regenstein, above n 63, 68.

${ }^{67}$ Paul H Hemsworth et al, Department of Agriculture, Fisheries and Forestry, A Scientific Comment on the Welfare of Sheep Slaughtered without Stunning (2009); Grandin and Regenstein, above n 63, 121.

${ }^{68}$ Gregory, above n 47, 11; Gregory et al, 'Time to Collapse Following Slaughter without Stunning in Cattle' (2010) 85 Meat Science 66, 68; Standing Committee on Agriculture and Resource Management, Parliament of Australia, Primary Industries Standing Committee Model Code of Practice for the Welfare of Animals: Livestock at Slaughtering Establishments, (2002), [2.6.3.1]; See also, Grandin and Regenstein, above n 63, 121.

${ }^{69}$ Gregory, above n 47; Gregory et al, above n 68, 68; Paul H Hemsworth et al, above n 67, [3].

${ }^{70}$ Grandin and Regenstein, above n 63, 125.

${ }^{71}$ Graeme McEwen, Animal Law: Principles and Frontiers (Barristers Animal Welfare Panel, 2011) <http://www.bawp.org.au/animallaw/>, 67 .
} 
delegate, AQIS. ${ }^{72}$ Live animals are considered 'goods' under the Export Control Act 1982 (Cth). ${ }^{73}$ They are 'prescribed goods' under the jurisdiction of the Australian Meat and Livestock Industry Act 1997 (Cth) ('AMLI Act'). ${ }^{74}$ Prescribed goods may only be exported by an individual holding a valid licence granted by the Secretary. ${ }^{75}$ The Secretary cannot grant a licence unless $\mathrm{s} / \mathrm{he}$ is satisfied that the applicant 'is competent to hold the licence and is (and is likely to continue to be) able to comply with licence conditions. ${ }^{76}$ The Secretary can announce any licensing conditions s/he considers appropriate, provided that they are not inconsistent with the regulations. ${ }^{77}$ The exporter must comply with any conditions imposed on the licence. ${ }^{78}$ An export licence holder who intentionally or recklessly contravenes a licence condition commits an offence. ${ }^{79}$ The Secretary may also decide to cancel, suspend or not renew the licence in the event of noncompliance with conditions. ${ }^{80}$

A licence holder must apply for a permit to ship a particular consignment of animals. ${ }^{81}$ The Secretary may grant a permit to export after $\mathrm{s} / \mathrm{he}$ has considered the applicant's compliance with licence conditions. ${ }^{82}$ An exporter must submit a notice of intention to export ('NOI') and a consignment risk management program ('CRMP') to the Secretary. ${ }^{83}$ The NOI must detail the type of animals to be exported, from where the animals will be sourced and where they will be kept while waiting for permission to leave for loading. ${ }^{84}$ The dates of transport, departure and arrival must also be included. ${ }^{85}$ The

\footnotetext{
${ }^{72}$ Pursuant to s 20 of the Export Control Act 1982 (Cth) the Secretary can delegate his or her powers to 'authorised officers'. Inspection powers have been delegated to AQIS.

${ }^{73}$ Export Control Act 1982 (Cth) s 3.

${ }^{74}$ Export Control (Animals) Order 2004 (Cth) O 1.04; see also, Caulfield, above n 11, 85.

${ }^{75}$ Export Control (Animals) Order 2004 (Cth) O 2.02.

${ }^{76}$ Caulfield, above n 11, 85. See also, Australian Meat and Livestock Industry Act 1997 (Cth) ss 10, 12, 22; Australian Meat and Livestock Industry (Export Licensing) Regulations 1998 (Cth) reg 14.

${ }^{77}$ Australian Meat and Livestock Industry Act 1997 (Cth) s 17.

${ }^{78}$ Australian Meat and Livestock Industry Act 1997 (Cth) s 15, s 17(1)(a); Rebecca Zaman and Ella Kucharova, 'Animal Welfare Legislation in Australia: The Federal Regulatory Framework' (2009) 94 Reform 60, 61.

${ }^{79}$ Australian Meat and Livestock Industry Act 1997 (Cth) s 54(3) 'imprisonment for 5 years'; Export Control Act 1982 (Cth) s 9; Caulfield, above n 11, 89.

${ }^{80}$ Australian Meat and Livestock Industry Act 1997 (Cth) s 24.

${ }^{81}$ Export Control (Animals) Order 2004 (Cth) O 2.58(1).

${ }^{82}$ Ibid O 2.59(2).

${ }^{83}$ Ibid Div 2.4.

${ }^{84}$ Ibid O 2.41(2).

${ }^{85}$ Ibid O 2.41(2)(ix), (xi).
} 
management of the animals throughout these processes must comply with licence conditions. ${ }^{86}$

After approval of the NOI, the exporter is permitted to

prepare to export the specified number and kind of livestock from the specified port in Australia on the specified day on board the specified ship to the specified country in compliance with the approved NOI. ${ }^{87}$

The animals must then be inspected by a veterinarian and a health certificate must be issued to the effect that an authorised officer has inspected the animals portside and is satisfied that they meet the standards of the importing country. ${ }^{88}$ If the health certificate is not issued, the animals cannot be exported. After the health certificate is issued, the exporter must apply for permission to leave for loading. Permission will be granted if the animals remain fit to travel. ${ }^{89}$ Once these conditions have been met, the Secretary may grant an export permit. ${ }^{90}$ The permit is valid for 72 hours. ${ }^{91}$

The conditions on board a ship are regulated by the Navigation Act 1912 (Cth) and Marine Orders Part 43. ${ }^{92}$ This legislation regulates ventilation and pen requirements for ships used in live exports. ${ }^{93}$

The export legislation does not properly contemplate animal welfare because it is designed to regulate the export of goods. As it currently stands, the Secretary may impose licensing conditions that require protection of animal welfare but, as will be discussed shortly, such protections may be removed as easily as they are made. Currently, it is a licence condition that the holder of a live-stock export licence may only export live-stock in accordance with the

\footnotetext{
${ }^{86}$ See, eg, ibid: The CRMP must set out 'the standards in the Australian Standards for the Export of Livestock relevant to the export and the exporter's plans to meet those standards': O 2.42(2)(b). A criterion for approval of the NOI and CRMP is whether they comply with the ASEL: O 2.44(2)(e).

${ }^{87}$ Ibid O 2.45(1).

${ }^{88}$ Ibid O 2.53. Permission to leave for loading is valid for five days, subject to the condition that the 'live-stock remain fit to travel': O 2.56 .

${ }^{89}$ Ibid O 2.54; see also, Caulfield, above n 11, 101.

${ }^{90}$ Export Control (Animals) Order 2004 (Cth) O 2.54.

${ }^{91}$ Ibid O 2.59(6).

${ }_{92}$ Marine Orders Part 43.

${ }^{93}$ Caulfield, above n 11, 79.
} 
Australian Standards for the Export of Livestock ('ASEL'). ${ }^{94}$ Therefore, an exporter must comply with the ASEL if they are to retain their licence.

The ASEL provide minimum animal welfare standards that must be met at each stage of the live-export process. They are prescribed by the government. These standards expressly incorporate the Australian Position Statement on Live Export and POCTA legislation. ${ }^{95}$ They apply to the sourcing and onfarm preparation of livestock, ${ }^{96}$ the land transport of livestock, ${ }^{97}$ the management of livestock in registered premises, ${ }^{98}$ vessel preparation and loading, ${ }^{99}$ and the onboard management of livestock. ${ }^{100}$ However, they are discursive, which makes it difficult to identify and prosecute breaches. ${ }^{101}$

The Standards are designed to ensure that only fit and healthy animals enter the live export chain and that those animals are treated humanely throughout. ${ }^{102}$ They specify when animals may be sourced and from which ports animals may be shipped. ${ }^{103}$ They also impose rest times and feed requirements and prescribe stocking densities. ${ }^{104}$ Pursuant to the ASEL, sheep must be kept dockside prior to shipment to allow the animals to be 'conditioned' to pelleted feed. ${ }^{105}$ Animals that are no longer fit for export at any stage must be removed from the consignment before loading. ${ }^{106}$ An exporter must also arrange for a stockman to travel with the animals. ${ }^{107}$ For

\footnotetext{
${ }^{94}$ Australian Meat and Live-stock Industry (Standards) Order 2005 (Cth) O 3.

${ }^{95}$ Department of Agriculture, Fisheries and Forestry, Australian Standards for the Export of Livestock: Version 2.3 (2011).

${ }^{96}$ Ibid Standard 1.

${ }^{97}$ Ibid Standard 2.

${ }^{98}$ Ibid Standard 3.

${ }^{99}$ Ibid Standard 4.

${ }^{100}$ Ibid Standard 5.

${ }^{101}$ See below Part IV(A).

102 Department of Agriculture, Fisheries and Forestry, Australian Standards for the Export of Livestock: Version 2.3 (2011): There is the expectation that any animals that do not satisfy the selection criteria will not be selected for live export. Ideally, pregnant or lactating animals, over-fat or anorexic animals, lame or sick animals and any animals displaying any signs of an infection should not be selected: s 1.6(1.7).

${ }^{103}$ Ibid Standard 1. Bos Taurus cattle may not be sourced from Northern Australian ports during summer months: Standard 1.5. Sheep may be shipped from Northern Australian ports only during the winter months: s 1.6 .

${ }^{104}$ See, eg, ibid s 2.14 (stocking density); s 2.8 (time without food and water); s 2.21 (rest time).

${ }^{105}$ Ibid s 3.8 .

${ }^{106}$ Ibid s 3.17 .

${ }^{107}$ Ibid s 5.1 .
} 
some voyages, an accredited veterinarian must also travel with the consignment. $^{108}$

POCTA legislation provides some protection of animal welfare by permitting only necessary, justified or reasonable harm. Yet protections against cruel treatment are watered down by defences in POCTA legislation allowing for compliance with Model Codes of Practice ('MCOP'). ${ }^{109}$ Individuals cannot be prosecuted if they acted in compliance with a MCOP as this is a complete defence to a cruelty charge. ${ }^{110}$ Currently, there is no MCOP in respect to the shipment of live animals. However, there is a MCOP in respect to land transportation of animals. This MCOP covers the carriage of animals from the farm to the feedlot prior to export.

\section{Current Problems}

The previous Part explained that there is currently minimal protection of animal welfare during live export. The live export regime falls well short of this limited conceptualisation of animal welfare. Animals are considered 'goods' in the live export process. ${ }^{111}$ Since they are objects, there is not much that can be done to protect their welfare as they are not perceived to have significant welfare interests. ${ }^{112}$ The role of the law is to provide a framework through which compliance with animal welfare standards may be monitored and enforced. This regulatory function is complicated by the fact that live export is governed by an amalgamation of federal government statutes, regulations and orders, industry codes and standards and POCTA legislation. ${ }^{113}$ The fundamental problem lies in the fact that most of these

\footnotetext{
${ }^{108}$ Export Control (Animals) Order 2004 (Cth) O 2.48.

109 Animal Welfare Act 2002 (WA) s 25; Department of Agriculture, Fisheries and Forestry, Australian Standards for the Export of Livestock: Version 2.3 (2011), Standard 3, 4.

${ }^{110}$ Animal Welfare Act 2002 (WA) s 25.

${ }^{111}$ Export Control Act 1982 (Cth) s 3.

112 See, eg, above $\mathrm{n} 7$.

113 Australian Meat and Livestock Industry Act 1997 (Cth); Australian Meat and Livestock Industry (Export Licensing) Regulations 1998 (Cth); Export Control Act 1982 (Cth); Export Control (Orders) Regulations 1982 (Cth); Export Control (Animals) Order 2004 (Cth); Department of Agriculture, Fisheries and Forestry, Australian Standards for the Export of Livestock: Version 2.3 (2011); Department of Agriculture, Fisheries and Forestry, Australian Position Statement on the Export of Livestock (2006); Prevention of Cruelty to Animals Act 1986 (Vic); Animal Welfare Act 2002 (WA); Animal Welfare Act 1993 (Tas). But note that the status of State animal welfare statutes is uncertain: Emanuel Exports Magistrates Court of WA (Criminal Jurisdiction) 8 February 2008. See also, Caulfield, above n 11, 79.
} 
instruments were not created to protect animal welfare but rather have been adapted to do so in response to public criticism of the regime. ${ }^{114}$

Live export is a national industry that requires uniform legal regulation governing the process from beginning to end. ${ }^{115}$ Yet presently, the key protections for animal welfare are the ASEL and POCTA legislation. The current law is problematic for numerous reasons. First, the legislation does not provide adequate protection for animal welfare. Second, there are multiple problems with enforcement of the provisions of the ASEL or POCTA legislation in the event of breach. Third, the decision in the case of Department of Local Government and Regional Development $v$ Emanuel Exports casts doubt on the applicability of state laws to the live export regime. ${ }^{116}$ Fourth, the actual standards for animal welfare that must be maintained are inadequate. In particular, the requirement that animals be deemed by a veterinarian to be healthy enough for export is, at best, window dressing. Fifth, the responsibilities of individuals involved at various stages of the live export chain are not always clear. Clarity is required so that each person is aware of their obligations and liable for failure to meet those obligations. Sixth, the lack of accountability of industry bodies has entrenched a state of inaction in enforcement of animal welfare protections. Finally, Australia's international trade obligations under the GATT may influence the manner in which Australia may protect animal welfare. This Part will examine each of these deficiencies and how they contribute to the failure to maintain adequate animal welfare standards throughout the live export process.

\section{A Failure to Protect Animal Welfare and Lack of Enforcement}

The current legislative scheme does not provide adequate protection of animal welfare. Animal welfare is primarily protected by the ASEL. Although these standards are predominately descriptive, they do incorporate POCTA legislation which prohibits the infliction of unnecessary harm to animals. ${ }^{117}$ Yet, the ASEL are integrated into the federal regulatory framework by secretarial orders. ${ }^{118}$ Unlike legislation, these orders are not enduring and are 'liable ... to stand or fall by the administrative fiat of the Secretary of

\footnotetext{
${ }^{114}$ Emanuel Exports Magistrates Court of WA (Criminal Jurisdiction) 8 February 2008, [101] (Crawford M).

${ }^{115}$ Keniry et al, above n 22, 33 .

${ }^{116}$ Magistrates Court of WA (Criminal Jurisdiction) 8 February 2008.

${ }^{117}$ Animal Welfare Act 2002 (WA) s 19.

${ }^{118}$ Australian Meat and Live-Stock Industry (Standards) Order 2005 (Cth) O 3.
} 
DAFF'. ${ }^{119}$ Thus, at any point in time, the Secretary may make another order stating that the Standards no longer apply. The ASEL's protection of animal welfare is therefore tenuous.

Lack of enforcement is a critical flaw in the current regime as it exacerbates the inadequate protection of animal welfare. There are two ways in which animal welfare standards could be enforced. First, at the Commonwealth level, a breach of a licence condition, including the ASEL, attracts penalties. Second, at the state level, a breach of POCTA legislation is punishable by either a fine or imprisonment or both. ${ }^{120}$

\section{$1 \quad$ Federal Enforcement}

Currently, at the Commonwealth level, AQIS fails to properly investigate and prosecute breaches of export licence conditions. ${ }^{121}$ This is due to the existing departmental culture whereby licence holders are viewed as clients. ${ }^{122}$ According to McEwen, investigation of compliance with licence conditions is not commonplace. Instead, AQIS sanitises 'its report[s] by deleting evidence of export licence breaches by its "clients", namely export licence holders'. ${ }^{23}$ Further, audit reports of export licence holders

are rated as 'acceptable', 'marginal', or 'unacceptable' ... [yet] the sanction applied with marginal or unacceptable audit outcomes is no more than an increase in 'audit frequency of supervision of consignments'. ${ }^{124}$

Thus, notwithstanding the power to revoke, suspend or refuse to renew a licence $^{125}$ in the event of a breach of an export licence condition, it appears that these powers are not exercised. AQIS's power to monitor the licensing system was granted following the Keniry Review because the self-regulated licensing system lacked accountability. Yet little improvement has been made.

\footnotetext{
${ }^{119}$ McEwen, above $\mathrm{n} 71,83$.

${ }^{120}$ Animal Welfare Act 2002 (WA) s 19 provides for a minimum penalty of a fine of $\$ 2000$ and a maximum penalty of a fine of $\$ 50000$ and 5 years imprisonment.

${ }^{121}$ McEwen, above $\mathrm{n} 71,82$.

${ }^{122}$ Ibid.

${ }^{123}$ Ibid.

${ }^{124}$ Ibid, 83.

${ }^{125}$ Australian Meat and Livestock Industry Act 1997 (Cth) s 24(1)(c), (d), (e).
} 
A licence is a privilege

which may be revoked if the regulated entity fails to comply with regulation to the requisite degree. This can ... encourage compliance and ... make it easier to stop a regulated entity in breach from engaging in the activity at all. $^{126}$

The lack of enforcement by AQIS undermines the efficacy of the live export licensing system. In the absence of enforcement, the licence system fails to function as intended: there is no incentive for entities to comply and no punishment if they do not.

\section{State Enforcement}

The use of POCTA legislation to protect animal welfare is a poor substitute for national animal welfare legislation. POCTA legislation varies from state to state. ${ }^{127}$ Although the Commonwealth government has published the Australian Animal Welfare Strategy with the stated aim of ensuring that state animal welfare protections are uniform, this uniformity is yet to be achieved. ${ }^{128}$ Consequently, because animals may be sourced in one state yet exported from another, they may be subject to multiple animal welfare regimes. This state-based approach fragments enforcement of protective provisions.

There is a lack of enforcement of POCTA legislation at state level due to a culture of indifference within states towards the live export trade. ${ }^{129}$ DAFF controls the live export trade as it is the department responsible for the issue and regulation of permits. Consequently, there is a presumption that federal departments will monitor compliance with welfare requirements. Furthermore, state organisations vested with the power to enforce or prosecute breaches of POCTA legislation may lack resources. Due to budget cuts to the Animal Welfare unit in Western Australia, only one inspector is currently employed by the State to monitor animal welfare compliance throughout the live export process. ${ }^{130}$ Consequently, 'animal welfare in WA is left entirely to

${ }^{126}$ Geoff Bloom, 'Regulating Animal Welfare to Promote and Protect Improved Animal Welfare Outcomes under the Australian Animal Welfare Strategy' (paper presented at AAWS International Animal Welfare Conference, Gold Coast, 1 September 2008), 36.

${ }^{127}$ McEwen, above $\mathrm{n} 71,1$.

${ }^{128}$ Department of Agriculture, Fisheries and Forestry, above $\mathrm{n} 45$.

${ }^{129}$ McEwen, above n 71, 34.

${ }^{130}$ Melissa Parke, Cuts to Animal Welfare Unit Unacceptable (19 April 2010) Melissa Parke MP <http://www.melissaparke.com.au/Latest-News/cuts-to-animal-welfare-unit-unacceptable .html>. 
non-government animal welfare organisations' such as the RSPCA. ${ }^{131}$ Whilst the RSPCA has the power to enforce POCTA legislation, it is a charity and has limited resources. It does not often prosecute, possibly because it does not want to bear the risk of cost orders. ${ }^{132}$ Further, a charity should not be expected to enforce the regime. The lack of enforcement leads to a lack of observance of the POCTA legislation as there is no fear of penalties for breach. $^{133}$

The Scope of POCTA Legislation and Extraterritoriality A further problem with state POCTA laws is that their application is limited to conduct within a state's borders. However, the ASEL impose liability for animal welfare from 'the period from the time the first animal is loaded onto the vessel until the last animal is unloaded at the port of disembarkation'. ${ }^{134}$ Accordingly, the ASEL are clearly designed on the assumption that POCTA legislation will operate extraterritorially throughout all phases of the live export process up to disembarkation. Yet, the ASEL are not a legislative instrument and thus cannot give state laws extraterritorial effect. Generally, state law can only apply to the edge of the state's territory, which ends at the low-water mark. ${ }^{135}$

To legislate extra-territorially, state parliaments must establish that 'a sufficient connection or nexus exists between the State and [the] extraterritorial effect of the law' and the state law is not inconsistent with Commonwealth law. ${ }^{136}$ In order to establish extra-territorial jurisdiction, states usually pass legislation accompanied by a clear statement to the effect that extra-jurisdictional application of the particular law is intended. ${ }^{137}$

Animal welfare laws pass the sufficient connection test. ${ }^{138}$ The test of sufficient connection has liberal application. Accordingly, 'even a remote or

\footnotetext{
${ }^{131}$ Ibid.

${ }^{132}$ McEwen, above $\mathrm{n} 71,34$.

${ }^{133}$ The degree of departmental apathy towards animal welfare issues was evident in Emanuel Exports Magistrates Court of WA (Criminal Jurisdiction) 8 February 2008 where a writ of mandamus was required to compel the department to properly investigate the matter: Animals Australia, Live Export 'Al Kuwait' Cruelty Complaint, (28 October 2010), Live Export: Indefensible $<$ http://liveexport-indefensible.com/facts/case.php $>$.

${ }^{134}$ Department of Agriculture, Fisheries and Forestry, Australian Standards for the Export of Livestock: Version 2.3 (2011), Standard 5.

${ }^{135}$ New South Wales $v$ Commonwealth ('Seas and Submerged Lands Case') (1975) 135 CLR 337.

136 Gerard Carney, The Constitutional Systems of the Australian States and Territories (Cambridge University Press, 2006) 210.

${ }^{137}$ Ibid 238.

${ }^{138}$ See, eg, McEwen, above n 71, 86.
} 
general connection will be sufficient'. ${ }^{139}$ Thus, 'any fact, circumstance, occurrence or thing in or connected with the territory' may occasion the imposition of liability. ${ }^{140}$ Alternatively, the 'relation may consist in presence within the territory, residence, domicile, carrying on business there, or even remoter connections'. ${ }^{14}$ All that must be established is that the law's operation is linked to the peace, order and good governance of the state. ${ }^{142}$ Animal welfare laws satisfy this test because animal cruelty is a criminal offence. ${ }^{143}$ Extra-territorial legislation by states in respect to crimes is well recognised by courts. ${ }^{144}$ Therefore, if states stipulate their intention to do so, they could provide for the extra-territorial reach of POCTA legislation. This would extend to cover the conduct of individuals involved throughout the live export chain including whilst the animals are on board a ship and in a foreign country. $^{145}$

However, even under the current legislation, it is arguable that persons involved in the live export trade who breach the legislation, either whilst in Australia or onboard a livestock carrier, could be prosecuted in Australia. A person may be charged with cruelty to an animal if the animal 'is transported in a way that causes, or is likely to cause, it unnecessary harm'. ${ }^{146}$ This does not require that harm in fact eventuates. ${ }^{147}$ The definition of 'likely' at law means 'something less than probability but more than a remote possibility; a real or not remote chance or possibility regardless of whether it is less or more

${ }^{139}$ Carney, above n 136, 224; Pearce v Florenca (1976) 135 CLR 507, 518 (Gibbs J); Union Steamships Company of Australia Pty Ltd v King (1988) 166 CLR 1, 14; Mobil Oil Australia Pty Ltd v Victoria (2002) 211 CLR 1, 22-3. See also McEwen, above n 71, 86.

${ }^{140}$ Broken Hill South Ltd v Commissioner of Taxation (NSW) (1937) 56 CLR 337, 375 (Dixon J).

${ }^{141}$ Ibid.

${ }^{142}$ Carney, above n 136, 217.

${ }^{143}$ See, eg, Animal Welfare Act 2002 (WA) s 19. Alternatively, the regulation of the welfare of live animals exported to foreign ports could fall within the category of 'carrying on a business'. If the animals were from the same state from which they were exported, the law is regulating animals (or goods) that are sourced from the state. This should be sufficient to establish a 'remote connection'.

${ }^{144}$ Carney, above $\mathrm{n} 136$.

145 According to McEwen, 'with the requisite connection established, state laws may also operate over the high seas': above n 71, 87. However, the Australian legislation only applies to Australian nationals. Accordingly, foreign nationals could not be prosecuted for breaches of the legislation.

${ }^{146}$ Animal Welfare Act 2002 (WA) s 19(3)(a) (emphasis added).

${ }^{147}$ Emanuel Exports Magistrates Court of WA (Criminal Jurisdiction) 8 February 2008, [79] (Crawford M). 
than 50 per cent'. ${ }^{148}$ Thus, individuals involved in the shipping process may be charged with cruelty offences if it can be established that, at the time of loading, it was likely that the animals would suffer harm on the journey itself, even if that harm did not, in fact, occur. Alternatively, individuals can be charged for conduct occurring during the time the ship spent in state jurisdictional waters. ${ }^{149}$ Thus, notwithstanding the ambiguity surrounding the extra-territorial scope of the legislation, if the regime was properly enforced, animal welfare could be protected.

\section{B The Case of Emanuel Exports and its Impact on the Protection of Animal Welfare}

The impotency of the current legislative scheme's protection of animal welfare was demonstrated in the case of Emmanuel Exports. ${ }^{150}$ In 2007, the Western Australian government, at the behest of Animals Australia, prosecuted an exporting company, Emanuel Exports, and its directors for animal cruelty. ${ }^{151}$ Animals Australia had obtained a writ of mandamus compelling the Department of Local Government and Regional Development to investigate the treatment of 103232 live sheep on the MV Al Kuwait in November $2003 .{ }^{152}$ The accused were charged with three counts of cruelty: ${ }^{153}$ transporting the sheep in a way likely to cause unnecessary harm; confining the sheep in a way likely to cause unnecessary harm; and failing to provide the sheep with proper food. ${ }^{154}$ The charges were confined to the first 24 hours on the ship, that being the time during which the ship was in territorial waters. ${ }^{155}$ The prosecution argued that the transportation of fat adult wethers during the second half of the year was cruel because they were more susceptible to inanition or salmonellosis and thus were more likely to die during passage. ${ }^{156}$ While the accused were found guilty of transporting the sheep in a way likely to cause unnecessary harm, Crawford $M$ found that the Animal Welfare Act 2002 (WA) ('AWA') gave rise to an operational

${ }^{148}$ Waugh v Kippen (1986) 160 CLR 156, 166-7 (Gibbs CJ). Although this definition was given in a different legal context, it has been used to define 'likely' as it is used in POCTA legislation: Emanuel Exports Magistrates Court of WA (Criminal Jurisdiction) 8 February 2008, [76] (Crawford M).

${ }^{149}$ Emanuel Exports Magistrates Court of WA (Criminal Jurisdiction) 8 February 2008.

${ }^{150}$ Ibid.

${ }^{151}$ Animals Australia, Live Export Cruelty Complaint, above n 133.

152 Ibid.

${ }^{153}$ Animal Welfare Act 2002 (WA) s 19.

${ }^{154}$ Emanuel Exports Magistrates Court of WA (Criminal Jurisdiction) 8 February 2008.

${ }^{155}$ Ibid [8] (Crawford M).

${ }^{156}$ Ibid [4] (Crawford M). 
inconsistency with the federal export licensing regime pursuant to section 109 of the Constitution and thus did not operate to the extent of that inconsistency. ${ }^{157}$ Crawford $\mathrm{M}$ found the defendants not guilty of the other two charges. ${ }^{158}$ The appeal against the decision was later dropped. Emanuel Exports is the only Australian case where exporters have been charged for cruelty to animals during live export. ${ }^{159}$ The case is significant for numerous reasons. First, it demonstrated the difficulty of enforcing POCTA legislation in relation to acts occurring during live export. Second, it showed the limited protection afforded by the legislation. Finally, it highlighted that the multiplicity of regulatory sources actually inhibits the protection of animal welfare during live export. Although the current regime is meant to enforce animal welfare standards, the case demonstrated the fallibility of the current law's protection of animal welfare.

As a consequence of the decision, it is possible that state legislation does not apply to the live export process due to its perceived inconsistency with federal export laws. ${ }^{160}$ Crawford $\mathrm{M}$ held that, whilst the Commonwealth regime contemplated and permitted the export of particular classes of sheep in November, the state law forbade this 'due to the likelihood of unnecessary harm', thus giving rise to an inconsistency because it criminalised the act of exporting the sheep even though the permit conferred a right to do so. ${ }^{161}$ In reaching this conclusion, her Honour found that an export permit constituted an indefeasible legal right to transport the animals in accordance with the NOI. ${ }^{162}$ With respect, the decision is incorrect. The issue of the permit does not constitute an indefeasible right. However, even if it did, the nature of the concurrent regulation of the regime is such that the issue of the permit is not inconsistent with the operation of the AWA. ${ }^{163}$

\section{The Erroneous Reasoning in Emanuel Exports}

A permit to export animals does not constitute an indefeasible right as the exporter has an ongoing obligation to have regard to 'mandatory animal

\footnotetext{
${ }^{157}$ Ibid [202] (Crawford M).

${ }^{158}$ Ibid [133], [142] (Crawford M).

${ }^{159}$ Cf Song $v$ Coddington [2003] NSWSC 1196 (17 December 2003). In that case, the AQIS accredited veterinarian was charged pursuant to POCTA legislation.

${ }^{160}$ Emanuel Exports Magistrates Court of WA (Criminal Jurisdiction) 8 February 2008.

${ }^{161}$ Ibid [194] (Crawford M).

${ }^{162}$ Ibid [194] (Crawford M).

${ }^{163}$ It should be noted that at the time of the decision, earlier versions of the ASEL and Export Control (Animals) Order applied. However, the relevant wording is the same and so, for consistency, the current versions of documents are being used in this discussion.
} 
welfare requirements' and ensure that adequate care is provided for the animals until they disembark. ${ }^{164}$ The granting of an export permit is conditional upon proof of compliance with this requirement. ${ }^{165}$ Thus, animal welfare obligations are ongoing as the regime requires compliance with them after the permit has been issued.

Crawford M's conclusion - that export was permitted because the licence was issued - is flawed. The issue of a permit in circumstances that are likely to cause harm to the animals during transportation is a jurisdictional error on the part of the Secretary. An administrative decision ${ }^{166}$ is reviewable if the decision-maker makes an error of law (but not of fact), ${ }^{167}$ fails to take into account a relevant consideration, ${ }^{168}$ or takes into account an irrelevant consideration. $^{169}$ If a decision is reviewable, it cannot constitute an indefeasible right. Under Crawford M's construction of the licensing system - that a permit constitutes an indefeasible right - it is presumed that all animal welfare requirements must have been met if the permit was issued because the Commonwealth officer was satisfied as to the conditions of transport. When issuing the permit, the Secretary is obliged to consider, inter alia, the extent of the licence holder's compliance with any licensing conditions, including animal welfare requirements such as those obligations in the POCTA legislation. ${ }^{170}$ Furthermore, the Secretary may refuse to grant a permit if $\mathrm{s} /$ he believes that the health or condition of the livestock may deteriorate during the journey. ${ }^{171}$ Thus, to issue an export permit, the Secretary is obliged to consider compliance with state animal welfare laws. ${ }^{172}$ In Emanuel Exports, the Secretary did not consider whether the consignment complied with animal welfare statutes because if $\mathrm{s} /$ he had, the permit would not have been issued because, as held by Crawford $\mathrm{M}$, the issue of the permit would have been likely to cause harm to the animals pursuant to POCTA legislation. Thus, s/he committed a jurisdictional error by failing to take into

\footnotetext{
${ }^{164}$ McEwen, above n 71, 75.

${ }^{165}$ Export Control (Animals) Order 2004 (Cth) O 2.59.

166 The decision to issue a permit should be construed as an administrative decision: Minister for Industry \& Commerce v Tooheys (1982) 60 FLR 325.

${ }^{167}$ Administrative Decisions (Judicial Review) Act 1977 (Cth) s 5(1)(b).

168 Ibid s 5(2)(b); Cohen v Peko-Wallsend Ltd (1986) 68 ALR 394 (Mason J); Murphyores Inc Pty Ltd v Commonwealth ("Fraser Island case") (1976) 136 CLR 1.

${ }^{169}$ Administrative Decisions (Judicial Review) Act 1977 (Cth) s 5(2)(a).

${ }^{170}$ Export Control (Animals) Order 2004 (Cth) O 2.59(2)(b).

${ }^{171}$ Ibid O 2.60(1).

172 Ibid O 2.59; Australian Meat and Live-stock Industry (Standards) Order 2005 (Cth); Department of Agriculture, Fisheries and Forestry, Australian Standards for the Export of Livestock: Version 2.3 (2011).
} 
account a relevant consideration. ${ }^{173}$ Accordingly, the permit to export was not an indefeasible right as there was a jurisdictional error. ${ }^{174}$

Crawford $\mathrm{M}$ also held that the regime gave rise to an operational inconsistency because the state law prohibited an act that was legal under the Commonwealth export regime. ${ }^{175}$ However, this construction is incorrect. Operational inconsistency arises when a state law 'alters, impairs or detracts' from a right or authority granted by a Commonwealth law. ${ }^{176}$ However, the Commonwealth regime clearly intends for state animal welfare laws to apply. First, there is no Commonwealth Act that is specifically directed towards regulating cruelty to animals. Anti-cruelty measures are included in the Environment Protection and Biodiversity Conservation Act 1999 (Cth), however the statute is limited to the importation or exportation of protected species pursuant to the Convention on International Trade in Endangered Species of Wild Flora and Fauna. ${ }^{177}$ Second, the federal export regime clearly intends state animal welfare laws to be incorporated in respect to live export. ${ }^{178}$ The Australian Position Statement provides that 'State and territory governments have responsibility for ensuring that livestock producers and

${ }^{173}$ Administrative Decisions (Judicial Review) Act 1977 (Cth) s 5.

${ }^{174}$ Ibid.

175 Emanuel Exports Magistrates Court of WA (Criminal Jurisdiction) 8 February 2008. However, there is no inconsistency because the Commonwealth and State Acts operate in different spheres. A direct inconsistency exists if the Commonwealth law intends to govern the field. The Commonwealth regime regulates the exportation of 'prescribed goods': Export Control Act 1982 (Cth) s 7. The State regime is concerned with animal welfare: Animal Welfare Act 2002 (WA). Thus, prima facie there is no inconsistency as the laws regulate different fields of behaviour. See, eg, Victoria $v$ The Commonwealth (1937) 58 CLR 618 'if it appears from the terms, the nature or the subject matter of a Federal enactment that it was intended as a complete statement of the law governing a particular matter or set of rights and duties, then for a State law to regulate or apply to the same matter or relation is regarded as a detraction from the full operation of the Commonwealth law and so is inconsistent': 630 (Dixon J).

${ }^{176}$ Ex parte McLean (1930) 43 CLR 472, 483 (Dixon J).

177 Environment Protection and Biodiversity Conservation Act 1999 (Cth) s 303 and s 303CA.

${ }^{178}$ Export Control Act 1982 (Cth) s 5. See also, Department of Agriculture, Fisheries and Forestry, Australian Standards for the Export of Livestock: Version 2.3 (2011): 'Livestock sourced for export must meet any relevant animal health and welfare requirements under state and territory legislation and relevant requirements under national Model Codes of Practice for the Welfare of Animals': s 1.6(1.1); 'The land transport of livestock for export must meet any relevant animal health and welfare and road transport requirements under state and territory legislation and relevant requirements under national Model Codes of Practice for the Welfare of Animals': s 2.6(2.1); 'Livestock sourced for export must meet any requirement under a law of a state or territory. State and territory governments are responsible for ensuring that these jurisdictional requirements are met under respective state and territory legislation': s 5.3(7). Compliance with animal welfare requirements is a precondition to the grant of an export permit: Export Control (Animals) Order 2004 (Cth) O 2.59; Caulfield, above n 11, 134-5. 
exporters comply with relevant state and territory legislation, including animal welfare Acts.' ${ }^{179}$ The ASEL stipulate that '[1]ivestock sourced for export must meet any requirement under a law of a state or territory'. ${ }^{180}$ Third, compliance with the ASEL — and thus also the POCTA legislation — is a licence condition. ${ }^{181}$ Fourth, the validity of an export licence is conditional upon the exporters' compliance with any licensing conditions imposed by the legislative regime. ${ }^{182}$ An offence is committed in the event of noncompliance. $^{183}$ Thus, non-compliance with state animal welfare laws is punishable under the Commonwealth regime. Contrary to the finding of Crawford $\mathrm{M}$, there is no inconsistency; ${ }^{184}$ rather, the regimes operate concurrently.

\section{The Impact of Emanuel Exports}

If Emanuel Exports is, in fact, good law, the decision highlights the absurdity of the current live export regime. The AWA clearly identifies cruel conduct and Crawford $M$ found that the animals suffered during transport. However, the federal regime sanctions that suffering by permitting the export of animals in those conditions. Thus, the system is unsound. To protect animal welfare if the trade continues, it should be a condition of the export licence and the export permit that state animal welfare laws will be complied with throughout the live export process until delivery.

\section{Veterinarians and Animal Welfare}

The standard of animal welfare required by live export regulation is hardly adequate. A critical aspect of the current protections is the requirement that animals be checked by a veterinarian prior to loading and that a veterinarian travel on certain voyages. These requirements were implemented following the Keniry Review. They are aimed at redressing the lack of supervision of

\footnotetext{
179 Department of Agriculture, Fisheries and Forestry, Australian Position Statement on the Export of Livestock (2006), 6.2.

${ }^{180}$ See, eg, Department of Agriculture, Fisheries and Forestry, Australian Standards for the Export of Livestock: Version 2.3 (2011), standard 5.3.

${ }^{181}$ Australian Meat and Live-stock Industry (Standards) Order 2005 (Cth).

${ }^{182}$ Australian Meat and Livestock Industry Act 1997 (Cth) s 15.

${ }^{183}$ Ibid s 54.

${ }^{184}$ See, eg, Clifford Pannam QC and Graeme McEwen, Memorandum of Advice, Department of Local Government and Regional Development (Prosecutor) and Emanuel Exports Pty Ltd (ACN 008676 131), Graham Richard Daws and Michael Anthony Stanton (Accused) (26 March 2008) $<$ http://www.bawp.org.au/current-issues/live-exports> [43].
} 
the animals throughout the journey and the allegations that exporters were manipulating mortality rates on the voyage.

Under the current system, there is a conflict of interest in the veterinarian's role. The veterinarians responsible for pre-loading health checks are employed by the exporter. Their role is to determine the 'health, welfare and fitness to travel' of the animals immediately prior to their loading. ${ }^{185}$ The issue of a health certificate is an essential precondition of the issue of an export permit. ${ }^{186}$ Thus, whilst veterinarians should be objective in their assessment of the animals, they may be 'subjected to pressure to report outcomes that meet the requirements of the exporter'. ${ }^{187}$ This is compounded by the lack of enforcement of statutory obligations. Although the Secretary may suspend or revoke their accreditation if the veterinarian does not perform their role properly, ${ }^{188}$ enforcement of these regulatory mechanisms is not a departmental priority. ${ }^{189}$ Given that the risk of getting caught is low, veterinarians may prioritise their interest in keeping their job over their duty to protect animal welfare.

Furthermore, the sheer magnitude of the task means that it cannot be properly accomplished by a single veterinarian. There may be thousands of animals being prepared for export. Pursuant to the legislation, the veterinarian must check all of the animals before issuing a health certificate. Yet, pragmatically, it is impossible for a single veterinarian to inspect every animal for signs of illness. ${ }^{190}$ This is evidenced in industry practice whereby sheep pass down a race in single file whilst veterinarians watch from the side. ${ }^{191}$ In Emanuel Exports, for example, '[o]ver 103,000 sheep were loaded over [two days]... [the veterinarian] observed the sheep momentarily, as they passed in the race, dockside, on their way on board'. ${ }^{192}$ This process fails to allow for sufficient analysis for subtle symptoms of illness that would render the animal unfit to travel.

\footnotetext{
${ }^{185}$ Ibid s 4.8.

${ }^{186}$ Export Control (Animals) Order 2004 (Cth) O 2.59(c)(iii).

${ }^{187}$ Keniry et al, above n 22, 40.

${ }^{188}$ Export Control (Animals) Order 2004 (Cth) O 4A.10.

${ }^{189}$ McEwen, above n 71, chs 10-11.

${ }^{190}$ Caulfield, above n 11, 95 .

${ }^{191}$ Emanuel Exports Magistrates Court of WA (Criminal Jurisdiction) 8 February 2008.

${ }^{192}$ Ibid.
} 
Third, when the animals are on board it is impossible for a veterinarian or stockperson to thoroughly check the health of every single animal. ${ }^{193}$ In Emanuel Exports, stocking density on board the ship was so great that inspection was performed from outside the pens. ${ }^{194}$ Consequently, it was not possible to see every animal or identify all signs of illness. ${ }^{195}$ The area was cramped because the 'ceilings in the pens were around $120 \mathrm{cms}$ high, sufficient clearance for sheep but not for a person to walk through without bending double ... [A] lot of scouring sheep, that is sheep with diarrhoea [a symptom of salmonellosis], were missed due to bad lighting. ${ }^{196}$ The prosecution argued that, due to the manner of confinement, sick animals were not humanely slaughtered and instead suffered unnecessary harm as they were left to die. ${ }^{197}$ As in the feedlot, it is unrealistic to expect that an individual, or a small crew, will be able to adequately monitor the health of thousands of animals. The dense overcrowding of the pens also complicates the task.

Finally, in some circumstances there is nothing that can be done to save a sick animal. The main causes of mortality on live export voyages - heat stress in cattle and inappetence and salmenollosis in sheep - 'are difficult to correct when detected'. ${ }^{198}$ Hence, the current standards do little to ensure animal welfare during the sea journey. A veterinarian's presence suggests that adequate treatment can be provided to the animals. However, this is not the case. Consequently, the veterinarian requirement adds nothing to the standard of animal welfare on the journey.

\section{Individual Responsibility for Animal Welfare}

Currently, the responsibility of each individual involved during the live export process is unclear. It is consequently difficult to enforce animal welfare obligations. Consistency and clarity are critical features of the criminal law: if

\footnotetext{
${ }^{193}$ Although veterinarians are not required on all shipments, a stockman is and they must monitor animal welfare: Department of Agriculture, Fisheries and Forestry, Australian Standards for the Export of Livestock: Version 2.3 (2011), Standards 4 and 5.

${ }^{194}$ Emanuel Exports Magistrates Court of WA (Criminal Jurisdiction) 8 February 2008, [116] (Crawford M).

${ }^{195}$ Ibid.

${ }^{196}$ Ibid [111]-[116], [117] (Crawford M).

${ }^{197}$ Ibid [119] (Crawford M). However, her Honour found that it was difficult to detect inanition in sheep and even if the pens were less crowded and areas were better lit, there was no guarantee that even all sick sheep would have been properly identified and humanely dispatched of: at [128].

${ }^{198}$ Philips, above n 19, 15. In serious cases of inanition, 'the condition is irretrievable' and the sheep will not eat any kind of feed: Emanuel Exports Magistrates Court of WA (Criminal Jurisdiction) 8 February 2008, [139].
} 
individuals are to face criminal sanction, the law must make clear what duties are owed or what conduct is proscribed. Criminal liability is imposed on those responsible for animals for failing to meet animal welfare requirements. Accordingly, identifying who is responsible for animal welfare during the live export process is critical to ensure that the imposition of criminal liability is justified. The imposition of liability is important because there is no commercial incentive for the exporter to monitor the welfare of animals after they reach the dock because that is when s/he is paid. ${ }^{199}$ Since animals are goods, any interest in the animals' welfare ${ }^{200}$ is extinguished upon payment.

For an individual to be prosecuted for failure to meet animal welfare requirements, they must be shown to have breached a licence condition ${ }^{201}$ or committed an act of animal cruelty. ${ }^{202}$ Accordingly, they must either be a licence holder or be considered to be 'responsible' for the livestock. However, the export chain is long. Thus, the question of who is 'in charge' of the animals is not clear-cut since it may vary during each stage of the journey. The Animal Welfare Act 2002 (WA) provides that a

'Person in charge' in relation to an animal, means -

a) The owner of the animal;

b) A person who has actual physical custody or control of the animal;

c) If the person referred to in paragraph (b) is a member of staff of another person, that other person; or

d) The owner or occupier of the place or vehicle where the animal is or was at the relevant time. ${ }^{203}$

At first glance, it appears that the exporter is responsible for the livestock throughout the export process. An exporter must ensure that 'sufficient livestock services are maintained throughout the voyage and that on-board care and management of the livestock is adequate to maintain animal health

199 Emanuel Exports Magistrates Court of WA (Criminal Jurisdiction) 8 February 2008. Crawford $\mathrm{M}$ found that the exporter was paid 'per head of sheep, delivered dockside [prior to shipping]. If sheep died during the voyage there was no reduction in the price paid': [27].

${ }^{200}$ Assuming their welfare is linked to monetary value. That is, they will receive more money for a healthy sheep than a sick sheep.

${ }^{201}$ Australian Meat and Livestock Industry Act 1997 (Cth) s 54.

${ }^{202}$ Animal Welfare Act 2002 (WA) s 19.

${ }^{203}$ Animal Welfare Act 2002 (WA) s 5. 
and welfare. ${ }^{204}$ This requires the provision of an accredited stockperson and 'competent animal handlers'. ${ }^{205}$ The exporter must also engage an accredited veterinarian for some shipments. ${ }^{206}$ However, the responsibility of the exporter is diluted by the ASEL, which suggest that once the animals are loaded on the vessel, the animals become the responsibility of the master. ${ }^{207}$ It is arguable that this releases the exporter from responsibility.

A better reading of the ASEL is that there is joint liability. The master can actually monitor the welfare of the sheep because s/he is on board. The exporter should ensure the crew that $\mathrm{s} /$ he sources are well versed in animal handling. However, the matter is not free from doubt and, until responsibility for animal welfare is clearly allocated, the wellbeing of animals may be compromised.

Furthermore, pursuant to sub-section (c) of the legislation, an export company may be vicariously liable for the conduct of their subcontractor if it is established that the subcontractor is a 'person in charge' and a member of the exporter's staff. Whether or not an individual is an employee is a question of fact and the intention of the exporter is not relevant. ${ }^{208}$ According to the NSW Supreme Court, the

concept of a person in charge ... refers to a person's ability and authority [to] take positive steps to effect [sic] the immediate physical circumstances of the animal so that person's authority might be employed to ensure care, treatment in a humane manner and the welfare of the animal. ${ }^{209}$

In Emanuel Exports, it was found that Norman House, a stockman on the vessel, was an employee of Emanuel notwithstanding that he was paid by the importer. ${ }^{210}$ This is because he was specifically asked by Emanuel to monitor

${ }^{204}$ Department of Agriculture, Fisheries and Forestry, Australian Position Statement on the Export of Livestock (2006), 6.1.

${ }^{205}$ Department of Agriculture, Fisheries and Forestry, Australian Standards for the Export of Livestock: Version 2.3 (2011), Standard 4.3(5).

${ }^{206}$ Department of Agriculture, Fisheries and Forestry, Australian Position Statement on the Export of Livestock (2006), 6.1; Department of Agriculture, Fisheries and Forestry, Australian Standards for the Export of Livestock: Version 2.3 (2011), s 5.6(5.1(b)).

${ }^{207}$ Department of Agriculture, Fisheries and Forestry, Australian Standards for the Export of Livestock: Version 2.3 (2011), s 4.3(2), 4.4(2), 4.6(4.16), 5.3(2), 5.4(2).

${ }^{208}$ Emanuel Exports Magistrates Court of WA (Criminal Jurisdiction) 8 February 2008, [26] (Crawford M).

${ }^{209}$ Song v Coddington [2003] NSWSC 1196 (17 December 2003), [66] (James J).

${ }^{210}$ The defendants argued that they were not in charge of the animals because pursuant to the contract of sale, the sheep became the property of the importer at the point of delivery of the sheep 'alongside the vessel'. They contended that they were not responsible for House's 
the welfare of the sheep while on board. ${ }^{211}$ Furthermore, he was a 'person in charge' under the Act because he was responsible for caring for the sheep and had the authority to euthanase animals if he believed it was necessary to do so. ${ }^{212}$ Emanuel was held responsible for House's failure to maintain adequate welfare standards. ${ }^{213}$ Thus, an exporter may be subject to criminal liability under POCTA legislation if their agents fail to adequately care for the animals in their charge. In addition, POCTA legislation regulates the conduct of stockmen, who are not otherwise subject to regulation under the Commonwealth regime because they are not licence holders. ${ }^{214}$

\section{E The Role of Industry Bodies}

A further problem is the role of industry organisations such as Meat and Livestock Australia ('MLA') and LiveCorp. Both these organisations are charged with monitoring the live export trade and MLA receives a levy of $\$ 5$ per head of cattle exported 'to address animal welfare issues' ${ }^{215}$ In the case of exports to Indonesia, that funding was used to provide numerous abattoirs with 'Mark I' boxes for cattle slaughter and to 'train' Indonesian abattoir workers. ${ }^{216}$ The Mark I boxes are 'designed to make a cattle [sic] fall down' before slaughter to make it easier to hold them down for slaughter, thus violating welfare standards that require animals be handled in such a way as to minimise stress. ${ }^{217}$ The success of the training is questionable, given that Australian representatives from MLA and LiveCorp visited one particular abattoir six times in 14 months to train the workers, ${ }^{218}$ yet footage broadcast by Four Corners showed workers from that abattoir abusing cattle prior to slaughter. ${ }^{219}$ Upon release of the footage, MLA claimed that it was 'as

conduct, even if he was a person in charge, because he was not an employee: See Emanuel Exports Magistrates Court of WA (Criminal Jurisdiction) 8 February 2008, [12]-[13], [23] (Crawford M).

${ }^{211}$ Emanuel Exports Magistrates Court of WA (Criminal Jurisdiction) 8 February 2008, [37] (Crawford M).

${ }^{212}$ Ibid [35] (Crawford M).

${ }^{213}$ Ibid [38] (Crawford M).

${ }^{214}$ Under the export regulation, punishment attaches to a breach of a licence condition, not animal cruelty per se: Australian Meat and Livestock Industry Act 1997 (Cth) s 54(3); Export Control Act 1982 (Cth) s 9.

${ }^{215}$ Commonwealth, Parliamentary Debates, Senate, 15 June 2011, 2880 (Rachel Siewert).

${ }^{216}$ Australian Broadcasting Corporation, 'A Bloody Business', Four Corners, 30 May 2011, $<$ http://www.abc.net.au/4corners/content/2011/s3230934.htm>.

${ }^{217}$ Ibid.

${ }^{218}$ Ibid.

${ }^{219}$ For example, by throwing water on them, breaking their tails, hitting them with ropes and sticks: see ibid. 
outraged as anyone that such acts took place', asserting that the organisation was unaware of animal handling practices. ${ }^{220}$ However, an MLA publication produced in 2005 notes that 'beef from Australian cattle is currently being discounted in the Asian marketplace' due to 'inappropriate pre-slaughter management and slaughter techniques'. ${ }^{221}$ Thus, for at least six years, MLA was aware of the treatment of animals in Indonesia. There are two possible explanations as to why nothing was done: either MLA did not take adequate or appropriate measures to remedy the problem or MLA tried to improve animal handling practices in Indonesia and was unable to effect change. No matter which reason is the correct one, it is clear that MLA is unable to ensure that animal welfare standards will be met during the live export process. This, alone, is sufficient reason to end the trade.

Animal handling practices in the Middle East and Egypt have also been scrutinised and criticised in the past, notwithstanding that LiveCorp and MLA claim to have a strong presence in both areas. The continued exposure of animal abuse suggests that it is endemic within the live export chain. Furthermore, it reflects poorly on MLA and LiveCorp's assertions that they work closely with local abattoirs to ensure that they meet Australian standards and that the treatment of animals is monitored. Rather, they respond only when deficiencies in their role as overseer are exposed to the public.

The lack of transparency in the functions of MLA and LiveCorp is compounded by the close relationship between these industry bodies and DAFF. Malcolm Caulfield suggests that 'the Commonwealth government department ... looks after industry interests ... [and] industry has a disproportionate influence in determining outcomes'. ${ }^{222}$ Arguably, this was evidenced in the lack of government oversight of the export programme.

Ultimately, enforcement of animal welfare standards through the live export process is dependent upon the combined effort of industry bodies and DAFF. MLA and Livecorp personnel must monitor the conduct of individuals in the importing countries. DAFF must ensure that licensing requirements are being

${ }^{220}$ David Palmer, Live Cattle Exports are Good for Animal Welfare, 22 June 2011, Meat and Livestock Australia, <http://www.mla.com.au/About-the-red-meat-industry/Livestockexports/Animal-welfare-in-Indonesia/Live-cattle-exports-are-good-for-animal-welfare>.

${ }^{221}$ That is, the quality and shelf life of the meat was affected by the stress caused to the animal during slaughter: Geoffrey Beere and Sharon Pettiford, 'Opportunities to Improve Slaughter Standards and Profitability in Indonesia' (June 2005) Meat and Livestock Australia 3 $<$ http://www.mla.com.au/CustomControls/PaymentGateway/ViewFile.aspx?GE3FxCYF50Sh 44VOfYuWDgHd40C25Ku/D/JjKCiueUR+/pgMVZ5b0aV4P04Q39Yg3EYMKKAfsht7d1T nt3BqiA $==$.

${ }^{222}$ Caulfield, above n 11, 17. 
met. The lack of accountability from industry organisations and their close relationship with government departments creates a conflict of interest that compromises the protection of animal welfare.

\section{F International Standards and Obligations}

International bodies fail to offer adequate protection of animal welfare. There are two international organisations that may exert influence over Australia's live export regime: the World Animal Health Organisation ('OIE') and the World Trade Organisation ('WTO').

The OIE is an international body dedicated to animal health and welfare. Membership of the organisation is voluntary. The organisation promulgates animal health and welfare guidelines with which member-countries are expected to comply. Yet, these guidelines are limited as they enshrine only minimal animal welfare standards since all members must agree to the terms. Consequently, OIE guidelines offer less protection for animal welfare than the standards currently enforced in Australia. For example, there is no requirement in the OIE guidelines that animals be stunned before slaughter notwithstanding the scientific literature that suggests that the suffering a conscious animal endures during slaughter is inimical to their welfare. ${ }^{223}$ Nevertheless, the OIE guidelines are used to calm public reactions to footage of live export. Upon resumption of trade with Indonesia, for example, one of the assurances provided by the Minister of DAFF was that the animals would only be exported to abattoirs that are compliant with OIE guidelines. However, given that this means animals are not necessarily stunned before slaughter, compliance with OIE standards is not synonymous with the protection of animal welfare.

Australia is also bound by the WTO's rules and the obligations imposed by the General Agreement on Tariffs and Trade ('GATT') which is 'designed to prevent and eliminate trade barriers'. ${ }^{224}$ Consequently, a country cannot discriminate between foreign nations when it is importing or exporting goods. ${ }^{225}$ This principle makes it difficult to limit trade on the basis of animal welfare concerns because 'the WTO does not recognize the treatment of

${ }^{223}$ World Organisation for Animal Health, Terrestrial Animal Health Code, (OIE, $20^{\text {th }}$ ed, 2009).

${ }^{224}$ A B Thiermann and S Babcock, 'Animal Welfare and International Trade' (2005) 24 Revue Scientique and Technique Office Internationale de Epizooties 747, 748.

${ }^{225}$ Peter Stevenson, 'The World Trade Organisation Rules: A Legal Analysis of Their Adverse Impact on Animal Welfare' (2002) 8 Animal Law 107, 110. 
animals as a legitimate basis on which to impose restrictions'. ${ }^{226}$ The United States, for example, unsuccessfully tried to restrict the importation of tuna from Mexico on the grounds that the methods used to catch the tuna were not dolphin-safe. ${ }^{227}$ Thus, the implementation of restrictions on the export of live animals from Australia 'may be viewed by some as a means of restricting trade'. ${ }^{228}$ The GATT does provide for some defences to justify restrictions to trade, including the defence that the restriction was '(a) necessary to protect public morals' or '(b) necessary to protect human, animal or plant life or health'. ${ }^{229}$ However, these defences have been interpreted narrowly, so that it is questionable whether they apply to animals. ${ }^{230}$ Consequently, when live export to Indonesia was suspended, the Indonesian government alleged that Australia was in breach of its trade obligations pursuant to the GATT. Thus, the GATT complicates the protection of animal welfare throughout the live export trade. The principles enshrined in the GATT relate to reducing trade barriers and concern commodities, not animals. Consequently, they do not provide adequate protection for animal welfare and arguably may inhibit efforts taken to restrict the live export trade on an ad hoc basis. ${ }^{231}$ The solution is a blanket ban on live export. A country will not be acting in a discriminatory manner if all exports of a particular kind are stopped to all countries. A ban on live export would protect animal welfare and ensure that Australia respects its international obligations.

\section{Reform OF Deficiencies}

Clearly then, the current live export regime fails to protect animals from harm. Animal welfare would be best protected if the live export trade were abolished because exported animals will continue to suffer harm even if regulation and enforcement are improved. However, while the trade continues, more needs to be done to alleviate the suffering of animals at all stages of the export process.

\footnotetext{
${ }^{226}$ Mike Radford, Animal Welfare Law in Britain: Regulation and Responsibility (Oxford University Press, 2001) 136.

${ }^{227}$ GATT Panel, Tuna-Dolphin DS29/R, 33 ILM 839 (16 June 1994).

${ }^{228}$ Thiermann and Babcock, above n 224, 748.

${ }^{229}$ General Agreement on Tariffs and Trade (30 October 1947) 55 UNTS 194.

${ }^{230}$ Thiermann and Babcock, above n 224, 748.

${ }^{231}$ See, eg, Stevenson, above n 225, 107.
} 


\section{A Abolition}

At its base, the live export regime will never meet adequate animal welfare standards because humans cannot ameliorate much of the suffering endured by the animals: they cannot force a sheep to eat pelleted food to save it from inanition; they cannot easily stop the spread of salmonellosis; they cannot quicken the acclimatisation process to minimise the risk of heat stress; and they cannot prevent the animals suffering trauma injuries as the livestock carriers navigate the open seas. While more regulation - or better enforcement of current regulation - may reduce the harm suffered, some form of harm will always exist. Given that there are alternatives to the live export regime, such as a frozen-meat trade, those alternatives should be adopted.

Currently, the live export trade survives on an economic argument that 'one should not justify preventing suffering to [animals] ... by causing suffering to farmers - the result of instantly depriving them of their livelihood'. ${ }^{232}$ This economic justification of the trade focuses on the fact that 'the jobs of more than 10000 people in remote, rural, regional and metropolitan areas including farmers, truck drivers, stockmen, stevedores and veterinarians are connected to livestock exports' that are supported by the live export industry. ${ }^{233}$ However, those who argue in favour of the live export trade refuse to accept the viability of a frozen or chilled meat export industry in lieu of live export. The view is taken that 'it is absurd to assert that the same product could be sold and transported packaged. That is not how our customers want it. ${ }^{234}$

The possibility of a frozen meat trade was recognised nearly two decades ago. The 1985 inquiry into the export of livestock from Australia recommended that 'the Federal Government should promote and encourage the expansion of the refrigerated sheep meat trade to the Middle East and other countries, with

\footnotetext{
${ }^{232}$ Noah (The Israeli Federation of Animal Protection Organisations) v The Attorney General; The Minister for Agriculture; The Egg and Poultry Board; Moshe Benishty and 31 Colleagues, Supreme Court of Israel, August 2003, [32] (Grunis J) ('Foie Gras Case').

233 Peter Thornber, Department of Agriculture, Fisheries and Forestry, The Australian Standards for the Export of Livestock (2008), 4. See also, Commonwealth, Parliamentary Debates, Senate, 7 December 2005, 90 (Senator Ian McDonald). Politicians are overwhelmingly concerned about the economic consequences of abolition of the trade. This is because, allegedly, '[t]he prospects for selling meat domestically from animals [that would usually be exported are] ... limited ... The meat from these animals is not what is demanded by Australian beef consumers. Meat from these animals is therefore unlikely to command a high price domestically': Frank Drum and Caroline Gunning-Trant, above n 57, 25.

${ }^{234}$ Commonwealth, Parliamentary Debates, Senate, 29 March 2006, 181 (Senator McGauren).
} 
the aim of eventually substituting it for the live export trade'. ${ }^{235}$ The fact that this was recognised two decades ago and has not been acted upon demonstrates the industry's resistance to reform.

Australia already exports a substantial amount of packaged meat. ${ }^{236}$ In 2008 it was stated that, 'sheep meat exports contributed $\$ 1.5$ billion to the Australian economy last year compared to the live sheep trade's \$341 million'.237 Markets for packaged meat in the Middle East, for example, have already been established in urban areas and the market for live animals for slaughter in the Middle East is confined to rural areas. ${ }^{238}$ Accordingly, the assertion that there is no consumer demand for pre-packaged meat products is questionable. Furthermore, 'a sheep processed in WA is worth approximately \$20 more to gross state product than a sheep sent overseas for slaughter. ${ }^{239}$ In the wake of the ban on live exports to Indonesia, it was noted that

the direct and indirect value of the red meat industry in Australia is something in the order of $\$ 17$ billion dollars [sic], and it employs some 55000 workers. By comparison, the live export trade comes in at about $\$ 1$ billion and 10000 workers. In other words, ending the live export trade will have a marginal effect. ${ }^{240}$

Thus, the current economic justification for the live export trade — that it is required to support Australian jobs - is tenuous, at best.

At the time of writing, two Bills seeking to ban live export were rejected by Parliament. The first was presented by the Greens Party. The proposed Live Animal Export (Slaughter) Prohibition Bill 2011 sought to amend the current Export Control Act 1982 (Cth), prohibiting the export of live animals for slaughter. ${ }^{241}$ The Bill proposed an immediate cessation of the live export trade. The Greens Party described 'the sheer cost of refitting dozens of slaughterhouses to meet Australian standards and retaining a highly transient workforce in improved animal welfare practices, when there is no imperative

\footnotetext{
${ }^{235}$ Senate Select Committee on Animal Welfare, above n 15, 186.

${ }^{236}$ Drum and Gunning-Trant, above n 57, 15.

${ }^{237}$ Commonwealth, Parliamentary Debates, House of Representatives, 16 November 2009, 11838 (Melissa Parke); Drum and Gunning-Trant, above n 57, 15.

${ }^{238}$ Drum and Gunning-Trant, above n 57, 15.

${ }^{239}$ Commonwealth, Parliamentary Debates, House of Representatives, 16 November 2009, 11838 (Melissa Parke), referring to ACIL Tasman, RSPCA Australia, Economic Analysis of Australian Live Sheep and Sheep Meat Trade (2009).

${ }^{240}$ Commonwealth, Parliamentary Debates, House of Representatives, 18 August 2011, 8526 (Andrew Wilkie).

${ }^{241}$ Commonwealth, Parliamentary Debates, Senate, 15 June 2011, 2880 (Rachel Siewert).
} 
to abandon traditional slaughter practices due to such poor working conditions' as 'simply astronomical' and therefore considered cessation as the cheaper option. $^{242}$

The second Bill was presented by independent Members of Parliament Nick Xenophon and Andrew Wilkie. The Live Animal Export Restriction and Prohibition Bill 2011 aimed to phase out live export by $2014 .{ }^{243}$ In the interim, the Bill required that Australian livestock be

kept overseas in holding premises that comply with the Holding Standards; are transported to slaughter, unloaded, kept in lairage and slaughtered in accordance with the OIE guidelines; and are stunned using appropriate humane restraints immediately before slaughter. ${ }^{244}$

Unfortunately, both Liberal and Labor party members voted against the Bills, in accordance with the policy of both the parties. It appears that both the major parties remained cowed by industry influence and the fear of losing the rural vote. Both parties refuse to consider the benefits of a chilled meat trade.

In early 2011, some Labor politicians lodged a notice of motion that 'supports moves towards the expansion of the frozen and chilled meat export industry using Australian halal stunned meat exports'. ${ }^{245}$ This notice of motion was unsuccessful. Following the rejection of the Live Export Bills, a second notice of motion was lodged, requiring that animals exported overseas be stunned before slaughter. This was also rejected by the Labor caucus. At the time of writing, the live export trade continues.

\section{B Establish a Federal System}

If live export is to continue, the regulatory system governing live export must be reconstructed so that it properly addresses animal welfare issues. ${ }^{246}$

${ }^{242}$ Commonwealth, Parliamentary Debates, House of Representatives, 20 June 2011, 6514 (Adam Bandt).

${ }^{243}$ Live Animal Export Restriction and Prohibition Bill 2011 (Cth).

${ }^{244}$ Commonwealth, Parliamentary Debates, House of Representatives, 4 July 2011, 7397 (Andrew Wilkie).

${ }^{245}$ Commonwealth, Parliamentary Debates, House of Representatives, 16 March 2010, 2989 (Janelle Saffin), Supported by Melissa Parke (Fremantle) and Dick Adams (Lyons): Gabrielle Dunlevy, 'Labour Move to End Live Export Grows' The Age (online), 12 October 2010 $<\mathrm{http}$ ://news.theage.com.au/breaking-news-national/labor-move-to-end-live-exports-grows20101012-16hrx.html>.

${ }^{246}$ As the regime currently stands, 'export policy ... licensing livestock exporters, inspection and health and welfare certification of livestock for export, and issuing export permits and 
Currently, the regime is 'focused on facilitating the export of livestock as cargo not animal welfare per se' ${ }^{247}$ To remedy this, the Commonwealth should legislate for uniform animal welfare laws and establish a federal department or independent regulatory body to enforce them. This would unify and streamline the animal welfare system in Australia. ${ }^{248}$

There are numerous heads of power under which the Commonwealth may legislate for animal welfare. Given that the majority of animals in Australia are farm animals that are bought and sold for slaughter, or for dairy and egg production, the Commonwealth could create an animal welfare agency pursuant to the trade and commerce power because farming falls within its ambit. ${ }^{249}$ Alternatively, since most animal businesses are conducted by companies, the government could use the corporations power. ${ }^{250}$ Finally, state governments could refer their power to legislate in respect to animal welfare matters. ${ }^{251}$

The issue then would be how the Commonwealth animal welfare regime could be regulated, given that a fundamental failure of the current regime is the lack of enforcement. A proper regulatory system should ensure that compliance with animal welfare requirements is a precondition to doing business. ${ }^{252}$ To improve on the lack of enforcement characterising the current regime, enforcement of punitive orders and offences should be assigned to a separate body. ${ }^{253}$

One option is to establish a federal department with a minister for animals. A branch of government would be more accountable to parliament than a private body. ${ }^{254}$ This would be a marked improvement on the current system: the live export regime is predominately comprised of delegated legislation, and thus is

health certificates' fall within the Federal Government's legislative ambit: Department of Agriculture, Fisheries and Forestry, Australian Position Statement on the Export of Livestock (2006), s 6.2 .

${ }^{247}$ Emanuel Exports Magistrates Court of WA (Criminal Jurisdiction) 8 February 2008, [101] (Crawford M).

${ }^{248}$ Zaman and Kucharova, above n 78, 61.

${ }^{249}$ Australian Constitution s 51(i).

${ }^{250}$ Australian Constitution s 51(xx). McEwen, above n 71, 34.

${ }^{251}$ Australian Constitution s 51(xxxvii).

${ }^{252}$ Zaman and Kucharova, above n 78, 61.

${ }^{253}$. McEwen, above n 71, 35.

${ }^{254}$ Zaman and Kucharova, above n 78, 61. 
not subject to the rigours of parliament. ${ }^{255}$ Alternatively, the approach of the United Kingdom could be followed. In Britain, an independent advisory council has been established to 'investigate, advocate and report' on the compliance with animal welfare standards. ${ }^{256}$ The advantage of this approach is that the body's sole purpose is to monitor the industry. However, it has no enforcement mechanism. Australia would thus have to modify this system. A third option is to charge state Attorney-General Departments, instead of the under-resourced RSPCA, with the enforcement of state animal welfare statutes. Overall, however, a federal system is preferred. By establishing a federal system, the Commonwealth government would signal 'an intention to contribute in a more meaningful way to animal welfare regulation' ${ }^{257}$

An attempt at establishing a federal animal welfare regime was evidenced in the proposed National Animal Welfare Bill 2005 (Cth). ${ }^{258}$ The Bill sought to establish a national Animal Welfare Authority independent of the government. ${ }^{259}$ It also suggested the establishment of a duty of care to be owed by individuals towards animals. ${ }^{260}$ Most importantly, the Bill proposed to regulate the live export regime by requiring that an export permit could not be granted unless the Secretary was satisfied that 'the laws and codes of practice relating to animal welfare that operate in the country to which the animals are to be exported provide comparable animal welfare standards and protection to the laws of Australia'. ${ }^{261}$ The Bill was not passed.

\section{Diplomatic Measures}

The Australian government's 'jurisdiction over the animals ceases when disembarkation is complete'. ${ }^{262}$ However, animals may be subjected to

\footnotetext{
${ }^{255}$ They are therefore 'not subject to wide public scrutiny': Steven White, 'Legislating for Animal Welfare: Making the Interests of Animals Count' (2003) 28 Alternative Law Journal $277,279$.

${ }^{256}$ Zaman and Kucharova, above n 78, 61.

${ }^{257}$ White, above n 255, 347.

${ }^{258}$ National Animal Welfare Bill 2005 (Cth).

${ }^{259}$ Ibid cl 8.

${ }^{260}$ Ibid $\mathrm{cl}$ 63. Note that this is substantially different to current POCTA legislation, which simply prevents the infliction of unjustified, unnecessary or unreasonable harm.

${ }^{261}$ Ibid cl 89(5).

${ }^{262}$ Department of Agriculture, Fisheries and Forestry, Australian Position Statement on the Export of Livestock (2006), 10 (figure 2).
} 
conduct that constitutes breaches of Australian animal welfare standards once they disembark at their ports of destination. ${ }^{263}$

The Australian government has tried to use diplomatic pressure to regulate the treatment of animals overseas. ${ }^{264}$ In 2006, Australia suspended live export trade with Egypt due to animal welfare concerns. ${ }^{265}$ Trade recommenced in late 2006 after two Memoranda of Understanding ('MOUs') were signed. ${ }^{266}$ Because MOUs are unenforceable, there is little that can be done in the event of breach: either the breach is allowed to continue or the trade must be stopped until new agreements are reached. In 2007, Animals Australia documented numerous breaches of the MOU provisions and, when the Egyptian government failed to explain the treatment, trade was suspended again. $^{267}$ Trade with cattle has recommenced but Australia still refuses to export sheep to Egypt. ${ }^{268}$

The licensing regime has been utilised to encourage compliance with the MOUs. For example, an MOU with Egypt requires that Australian cattle must be slaughtered at an approved abattoir. ${ }^{269}$ To ensure that this happens, licence conditions have been imposed requiring exporters to show that animals are being transported to Sokhna, the port closest to the approved abattoirs. ${ }^{270}$ All cattle must be fitted with an electronic tracking device ('ETD') in their ear-tag before they are loaded for export. ${ }^{271}$ This approach could be employed in respect to all live exports to ensure that the animals are not sold to private purchasers and are taken to abattoirs that meet Australian standards.

But there are still problems. Once the animals disembark at their port of destination, responsibility for their care is transferred to the importer pursuant to the ASEL. ${ }^{272}$ An importer does not require a licence and thus has no incentive to abide by the licensing conditions such as the ASEL. Notwithstanding the obligations imposed upon the exporter to ensure that the

\footnotetext{
${ }^{263}$ Caulfield, above n 11, 77.

${ }^{264}$ See, eg, Caulfield, above n 11; McEwen, above n 60 [3]; McEwen, above n 71, 67.

${ }^{265}$ See above Part III.

${ }^{266}$ McEwen, above n 71, 67.

${ }^{267}$ Ibid [4].

${ }^{268}$ Australian Meat and Live-stock Industry (Export of Live-stock to Egypt) Order 2008 (Cth).

${ }^{269}$ McEwen, above $\mathrm{n} 71,67$.

${ }^{270}$ Australian Meat and Live-stock Industry (Export of Live-stock to Egypt) Amendment Order 2011 (Cth) O 6.

${ }^{271}$ Ibid O 6(1).

${ }^{272}$ Department of Agriculture, Fisheries and Forestry, Australian Standards for the Export of Livestock: Version 2.3 (2011).
} 
cattle are traceable, if the animals were transferred to a different abattoir after they were unloaded at Sokhna, there is little that Australian government officials could do about it: while the penalties for breach are directed at the exporter, the issue here is the conduct of the importer, who is not subject to the licensing regulation system. Thus, there is a fundamental problem in exporting animals to countries with different animal welfare standards. This problem can be addressed only by abolition.

\section{CONCLUSION}

It can be seen that the current live export regime suffers from many deficiencies. Animal welfare protection is unsound as it may be revoked at any time at the will of the Secretary. Standards for animal welfare are not enforced due to bureaucratic apathy. Animal welfare requirements imposed by the Commonwealth regime are inadequate and do little to protect animal welfare during the live export process. The structure of the regulatory regime is such that it is unclear who is responsible for animals at all times throughout the live export process. There is also ambiguity surrounding the applicability of POCTA legislation. Although it is not inconsistent with the Commonwealth regulatory regime, until Emanuel Exports is overturned it appears that POCTA legislation will not operate after the issue of an export permit. Finally, international standards such as the OIE are inadequate as they impose animal welfare standards that are lower than those currently required in Australia.

Having regard to the above deficiencies, it is incomprehensible that the current system has persisted as long as it has. For more than two decades, economic concerns have prevented the abolition of the trade. Yet the humane treatment of animals dictates that live export be abolished. Until this is achieved and animal welfare is protected, Australia continues to trade pain for profit. 